\title{
The Rhetoric of Inaction: Failing to Fail Forward in the EU's Rule of Law Crisis
}

January 30, 2021

\author{
Cassandra Emmons \\ Postdoctoral Fellow \\ Weatherhead Center for International Affairs \\ Harvard University \\ cemmons@,fas.harvard.edu \\ http://cvemmons.wixsite.com/website
}

\author{
Tommaso Pavone (corresponding author) \\ Postdoctoral Fellow \\ PluriCourts Centre \\ University of Oslo \\ tommaso.pavone@jus.uio.no \\ https://www.tommasopavone.com/
}

\begin{abstract}
In the EU, political crises often serve as catalysts for policymaking and 'failing forward'. Yet as a breakdown of the rule of law has swept some member states, EU institutions have repeatedly failed to act. We argue that this outcome is partly tied to how political elites strategically mobilize rhetoric to legitimate stasis in moments of crisis. Building on theories of rhetorical action and discursive institutionalism, we rectify their bias for change and draw on Albert Hirschman's work to theorize 'rhetorics of inaction': A coordinative discourse wielded by national and supranational actors to reconcile divergent preferences and justify stasis by appealing to the very policies and values threatened by a crisis. We specify the conditions under which rhetorics of inaction are most likely to pervade EU policymaking and illustrate the theory's explanatory purchase in a case study of the EU's (non-)responses to the constitutional breakdowns of Hungary and Poland. By tracing the discursive interactions between EU and government officials, we demonstrate that populist and partisan affronts on the EU conceal far more sophisticated and effective argumentative strategies behind-the-scenes. We conclude that rhetorical politics are central to understanding the EU's failure to respond to crises, and elaborate avenues for future research.
\end{abstract}

Keywords: rule of law, democratic backsliding, European Union, rhetoric, failing forward

Acknowledgements: We would like to thank Erik Jones, R. Daniel Kelemen, Sophie Meunier, Dimitry Kochenov, Joelle Grogan, Kim Lane Scheppele, Laurent Pech, Tomek Koncewicz, John Morijn, participants of the "Failing Forward or Falling Apart?" workshop held in September 2019 at Princeton University, and participants of the 2020 Law and Society Association virtual annual meeting for constructive feedback and helpful comments. All remaining errors are our own. 
To us in Hungary, democracy and freedom are not political questions, but moral questions. You now seek to pass moral judgement and stigmatise a country and a people on the basis of a numerical majority... If we truly want unity in diversity, then our differences cannot be cause for the stigmatisation of any country, or for excluding it from the opportunity of engaging in joint decision-making. We would never sink so low as to silence those with whom we disagree.

--Viktor Orbán speech to the European Parliament, September 11, $2018^{1}$

What better way to show him up as half foolish and half criminal than to prove that he is achieving the exact opposite of what he is proclaiming as his objective?

--Albert Hirschman, The Rhetoric of Reaction, p. 19

\section{Introduction: Rhetorical Affronts to 'Failing Forward'}

The European Union (EU) has long been understood as a polity built through crises. When political or economic turmoil erupts, member states embrace lowest common denominator policy solutions to overcome a dearth of foresight or a prior inability to compromise. Over time, these institutional patches falter in the face of subsequent economic or political shocks to spark new crises and opportunities for policymaking. In its most recent and sophisticated iteration, Jones et al. (2016) theorize this dynamic as 'failing forward' ('FF').

However, not all crises catalyze policymaking and FF. Since 2010, the EU has faced the alarming constitutional breakdown of Hungary and Poland, including the dismantling of judicial independence and press freedom, harassment of NGOs, criminalization of dissent, and undermining of fair elections (Scheppele, 2018; Sadurski, 2019; OSCE, 2018). Even as this 'rule of law crisis' ('ROLC'; see Kelemen 2019; Smith 2019) threatens the legal and democratic values enshrined in Article 2 of the Treaty on EU ('TEU'), the EU has been 'paralyzed by fear' and stuck in an 'equilibrium' of inaction (Bakke \& Sitter 2020, p.1; Kelemen 2020). This (non)-response is particularly striking because, according to one of the FF theory's co-authors, the rule of law crisis 'poses by far the greatest risk - arguably the only truly existential risk' to the EU's institutional survival (Kelemen, 2019, p.247). ${ }^{2}$

Recent studies have attributed this stasis to institutional gridlock and rational preferences, namely the conjunction of partisan efforts in Parliament to shield allied autocrats (Kelemen, 2020; Closa 2020), intergovernmental opposition to supranational interference in the Council (Closa, 2020), and the Commission's reluctance to embrace enforcement without broad state support (Sedelmeier 2017; Closa 2019). Without challenging these accounts, we argue that they raise an underappreciated dilemma for the EU: Inaction in the face of crisis contradicts EU officials' hard-wired reflex to 'never let a serious crisis go to waste' (Degner 2019, p.253) especially when the Union's fundamental values as a liberal 'community based on the rule of law'3 are at stake (Kelemen, 2019, p. 247). To openly concede partisan coddling, state complicity, and supranational timidity would only exacerbate 'Europe's crisis of legitimacy' (Schmidt 2020). So how has the EU's failure to respond to a serious crisis been justified and perceived as a legitimate outcome?

\footnotetext{
${ }_{1}$ See Transparency Appendix (Trax) 3.

2 This follows Schimmelfennig (2017, p.316)'s definition of an EU crisis as 'a decision-making situation with a manifest threat and a perceived significant probability of disintegration'. The ROLC was also labelled a 'crisis' in 2013 by Commission Vice-President Reding, see Trax.25.

${ }^{3}$ C-294/83, Les Verts v. European Parliament [1986] ECR 1339, par. 23.
} 
To tackle this puzzle, we draw on theories of 'rhetorical action' and 'discursive institutionalism' (Schimmelgennig, 2001; Schmidt 2008), but we elaborate these frameworks in a novel direction: Instead of treating rhetoric as a mechanism for change - a tool to legitimate failing forward (ex. Schimmelfennig 2001, Schmidt 2013) - we theorize how rhetorical action is strategically mobilized to justify inaction and legitimate failures to respond to crises. We argue that the EU's (non-)response to the ROLC has gone hand-in-hand with the institutional entrenchment of what we call a rhetoric of inaction: A coordinative discourse wielded by a constellation of national and supranational actors to legitimate stasis by appealing to the very policies and values threatened by a crisis.

To this end, the rest of this article is organized as follows. We first justify a case study analysis of the ROLC by arguing that it fits uneasily within existing understandings of EU crisis policymaking - particularly Jones et al. (2016)'s FF theory. Next, we argue that research on the ROLC cannot fully account for the EU's reluctance to act without taking rhetorical action seriously. Third, we rectify the 'bias for change' in theories of rhetorical action and discursive institutionalism (Dawson \& Hanley 2019, p.715) by theorizing rhetorics of inaction, drawing upon the work of Albert Hirschman (1991). We also specify the substantive characteristics and contextual conditions that rhetorics of inaction must meet to effectively serve as a coordinative discourse in the face of crisis. Fourth, we assess these theoretical expectations against the historical record by tracing the discursive interactions between EU and Hungarian and Polish officials, leveraging primary and secondary sources compiled in a Transparency Appendix (Trax; see Moravcsik 2014). Fifth, we empirically assess scope conditions for these rhetorics of inaction. We conclude by underscoring the perils of passivity in the face of crisis, the imperative for counter-rhetorics of action, and future research paths.

\section{The Rule of Law Crisis and the Limits of Existing Explanations}

The severity and persistence of the ROLC calls for revisiting longstanding debates on the nature of crisis bargaining and policymaking in the EU. Jones et al. (2016)'s FF theory synthesizes these debates by positing that political crises are caused by institutional incompleteness, which prompts intergovernmental bargains and lowest-common denominator policy solutions. Functional spillovers then provide momentum linking one crisis to the next. In light of this narrative of institutional change, the ROLC simultaneously constitutes a 'most likely' and a 'deviant' case.

The ROLC is a most likely case for the FF theory in two respects. First, the EU's incomplete architecture for rule of law enforcement was born out of lowest-common denominator intergovernmental bargaining. Member states debated how much authority to delegate to the EU over rule of law enforcement during the Amsterdam Treaty conferences, producing a sole provision that serious breaches of the values enshrined in Article 2 TEU could trigger the suspension of membership rights via a unanimous vote in the Council - an onerous threshold mandated by Article 7 TEU (Sadurski, 2010). Second, the ROLC constitutes a serious crisis for the EU, threatening the integrity of its legal order, empowering autocrats to derail intergovernmental negotiations over critical policies, exposing the EU's incapacity to enforce its core values, and eroding the EU's soft power and legitimacy abroad (Kelemen, 2019; Smith 2019). European officials should have thus been expected to swiftly act against the Hungarian and Polish governments. 
This is precisely where the trajectory of the ROLC deviates from the expectations of the FF theory. Since 2010, EU institutions have discussed the crisis often, yet the Commission has favored dialogue over enforcement and the Council has dragged its feet, failing to act on two Article 7 referrals against Hungary and Poland to impose sanctions (Soyaltin-Colella, 2020). A chorus of frustrated observers routinely lament how 'the European Union and the Member States seem to be doing as little as they can to resolve this situation' (Kochenov, 2017, p.9). Because this outcome deviates from theoretical expectations and the historical patterns of EU crisis policymaking, it is uniquely suited for probing 'why observed outcomes do not fit' (Levy, 2007, p.8).

To explain this puzzling outcome, existing analyses have focused on the conjunctive effect of institutional rules and divergent preferences across member states, the Parliament, Council, and Commission (ex. Closa 2019, 2020; Kelemen 2020). Yet these studies also uncover suggestive evidence that more discursive logics played a key role. First, EU and state officials consistently privileged dialogue-centric procedures in intergovernmental, closed-door settings to debate the ROLC (Sedelmeier 2017; Uitz 2019; Closa 2020; Blauberger and Van Huellen 2020) - thereby sidelining more transparent or adversarial fora like the European Court of Justice, which has consistently supported vigorous rule of law enforcement (Kochenov and Bard 2019). ${ }^{4}$ Second, Closa (2019, pp.10-11; 2020, pp.708-709) notes that Commission officials harbored a number of 'fears' concerning the perceptions and unintended consequences of EU rule of law enforcement, while Sedelmeier (2017, p.344) and Blauberger and Van Huellen (2020, pp. 7, 13) add that the impact of any enforcement actions 'depends on their legitimacy' and impartiality. Our goal is to theorize how a dialogue-centric approach and the legitimacy concerns of European officials have shaped the EU's (non-)response to the ROLC, to complement existing rational-institutionalist accounts.

\section{The Rhetoric of Inaction: Theory and Methods}

We propose a theory of 'rhetorics of inaction' that builds upon the literature on rhetorical action and discursive institutionalism (Schimmelfennig 2001; Schmidt 2008). These frameworks posit that in institutional sites characterized by 'arguing and bargaining', 'actors need to give reasons why they prefer certain courses of action and or why their interests are justified' (Elster 1999; Risse 2000, p.8). Political elites are incentivized to 'hide base motives' behind 'norm-based arguments' invoking the 'standards of legitimacy' and 'logics of appropriateness' ensconced in a given institutional setting (March \& Olsen, 1998, pp.951-952; Neyer 2003, p.694; Schimmelfennig 2001, p.63). The persuasiveness of rhetorical action is bolstered if it is deployed consistently (Elster 1999; Schimmelfennig 2001, p.65) and serves as a 'coordinative discourse' to reconcile preference heterogeneity, particularly in fragmented polities like the EU (Schmidt 2013, p.188).

We build on this research program in two ways. The few discursive analyses of the ROLC that exist have focused on rhetorical strategies for domestic public audiences (Schlipphak \& Trieb 2017; Dawson \& Hanley 2019), thereby neglecting the more concealed hearings in the Council and the

\footnotetext{
${ }^{4}$ The ECJ has crafted a jurisprudence legitimating vigorous EU rule of law enforcement (Kochenov and Bard 2019), but courts cannot resolve serious crises without political support (Blauberger and Kelemen 2017). For instance, the ECJ depends on the Commission to bring infringement actions under Article 258 TFEU, but the Commission has been reluctant to do so (Scheppele et al., 2021).
} 
interactions between member states and the Commission or Parliament. We focus instead on these fora wherein EU responses to the ROLC have been deliberated, delayed, and ultimately derailed. Second, research on rhetorical action exhibits a 'bias for change' (Dawson \& Hanley 2019, p.715) by focusing on pro-integration rhetoric (Schimmelfennig, 2001) and discursive interactions that destabilize the institutional status-quo in times of crisis (Schmidt, 2013). Conversely, we argue that rhetorical action can also oppose change and lock-in the status-quo, and this act can matter most precisely during crises that 'generate additional pressures to increase integration' (Jones et al., 2016, p.1014).

How can rhetoric be wielded to resist change? To answer, we look to the work of Albert Hirschman. In a magisterial historical analysis of the extension of citizenship policies from the $18^{\text {th }}$ to the $20^{\text {th }}$ centuries, Hirschman (1991, pp.1-3) traced how these 'progressive thrusts have been followed by ideological counterthrusts of extraordinary force.' In particular, policymakers resisting reform perfected a tripartite 'rhetoric of reaction': Arguments that policies should be opposed because they will either backfire (the perversity thesis), put other hard-won policy achievements at risk (the jeopardy thesis), or prove useless (the futility thesis). These rhetorics' persuasiveness lies in their being mobilized strategically 'against a policy one abhors, but whose announced aim one does not care to attack headon' (Hirschman 1991, pp.12-19). They disarm change advocates by prophesizing that 'wellintentioned' policies would ultimately undermine the very aims and values they sought to advance.

We posit that the jeopardy, perversity, and futility theses have also gained currency as justifications for the EU's (non-)response to the ROLC, and our goal is to assess this expectation against the historical record. To this end, we adapt Hirschman's (1991) framework in three ways. First, Hirschman's examples of rhetorical action comprise responses to progressive policy thrusts (hence his language of rhetorics of reaction). Alternatively, we posit that these strategies can also be wielded preemptively. Since our goal is not to explain rollbacks of EU policies, but how the EU's failure to act in times of crisis is legitimated in the first place, we prefer the terminology of rhetorics of inaction.

Second, Hirschman tied these rhetorical affronts to a coherent set of recalcitrant domestic actors. Yet if discursive institutionalists are right, governments mobilizing rhetorics of inaction as a 'communicative discourse' to galvanize domestic audiences are unlikely to gain currency in the EU unless they are also useful as a 'coordinative discourse' for their supranational and progressive interlocutors (Schmidt 2013). Furthermore, when progressive policymakers traffic in rhetorics of inaction, they bolster their persuasiveness and legitimate them because the credibility of arguments is conditioned by 'the credibility and truthfulness of speakers' (Ulbert \& Risse, 2005, p. 359). We therefore expect these arguments to be tailored for, appeal to, and be employed by well-intentioned EU officials and national governments with diverse interests.

Lastly, Hirschman advanced a purely descriptive genealogy of conservative arguments. In contrast, we set out to identify the 'permissive conditions' (Soifer, 2012) that enable rhetorics of inaction to gain currency in EU crisis deliberations. We build on the aforementioned literature to derive three conditions under which rhetoric is most likely to serve as a legitimation for the EU's failure to respond to crises:

(1) When it frames inaction as a means to protect the EU's core values and existing policies; 
(2) when it is deployed consistently, and its prophetic warnings are plausible enough to be taken seriously by political elites inclined to act; and

(3) when it supplies norm-based arguments that are useful to national and supranational political elites to reconcile beterogenous preferences.

To empirically assess these claims, we analyze the discursive interactions between EU institutions and the Hungarian and Polish governments since 2010. Drawing on Beach and Pedersen (2019, pp.99$100)$ 's mechanistic approach to process tracing and Schimmelfennig (2001, p.48)'s conception of rhetorical action as an 'intervening mechanism', we undertake a theory-guided search for entities (national governments or representatives, EU officials) engaging in activities (rhetorical action) that leave observable traces at key junctures in the historical record. By 'key junctures,' we mean moments when EU responses to the ROLC - such as using the Article 7 procedure to impose sanctions - were deliberated, particularly events where the 'dogs did not bark' (moments that might have reasonably triggered EU rule of law enforcement, but where action was delayed or renounced). Following Waldner (2015), we summarize these junctures in an 'event history map' (Figure 1) that organizes our analysis and maps out our empirical evidence.

Figure 1: Event history map of EU discursive interactions in the ROLC, with Trax evidence labeled

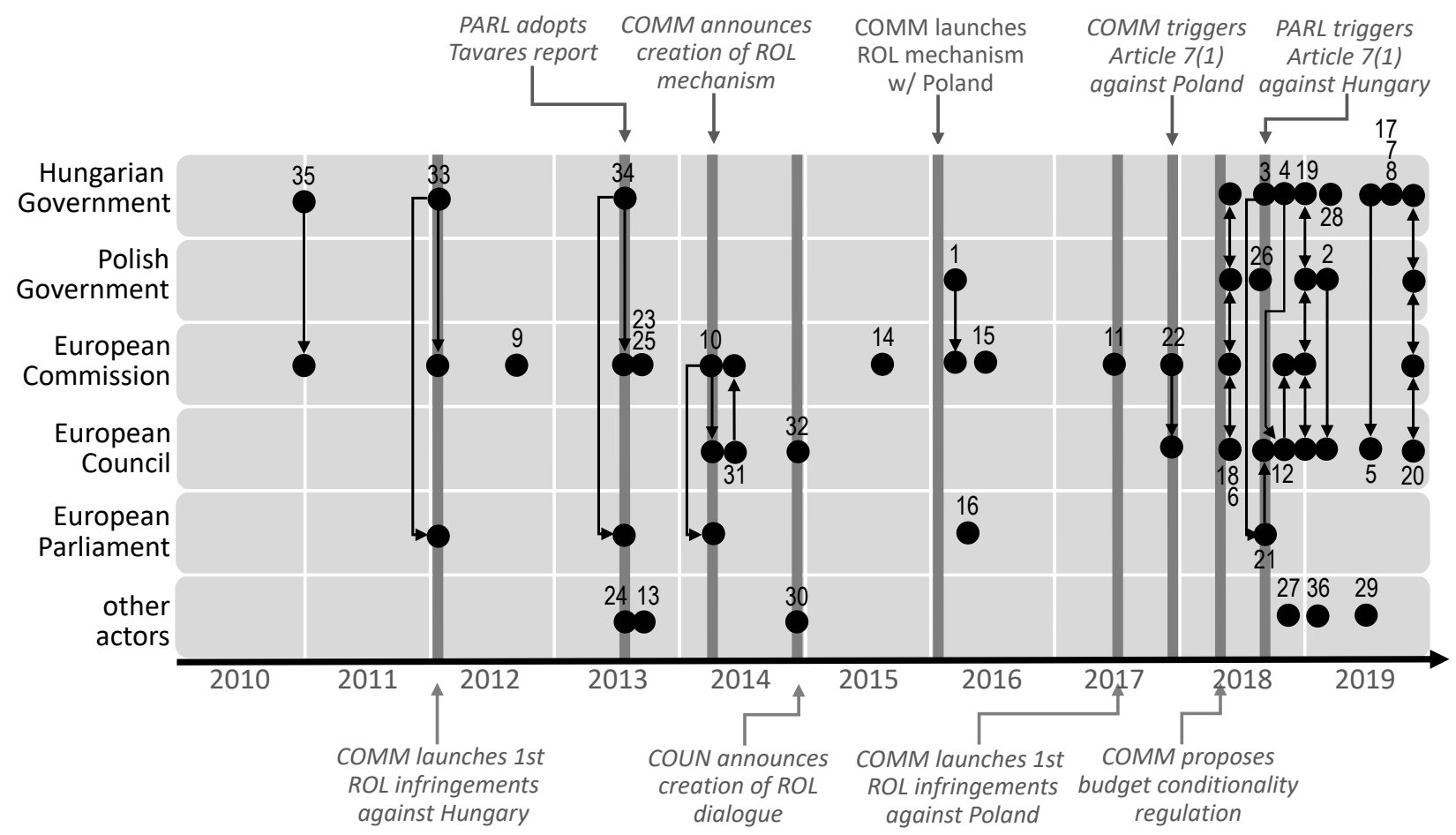

Note: Arrows in Fig. 1 represent directional communications (ex. government letter to the Commission); no arrows represent communications to a generic audience (ex. press release). The events (and evidence) in Fig. 1 are not exhaustive: For reasons of space, we focus on the most salient events identified by the existing literature. For full list of documents consulted, see Table 1 in the Trax.

To identify whether (and which) rhetorics of inaction have taken root in intergovernmental deliberations represented in Figure 1, we place particular evidentiary weight on records of internal 
deliberations within the Council and between national governments and Commission officials. Several of these documents have been made available through Freedom of Information requests or leaks to scholars and journalists. These materials allow us to focus on which 'coordinative discourses' take root in the EU's institutional settings, allowing us to compare their effectiveness to overtly partisan and populist 'communicative discourses' in the public sphere that have hitherto garnered most scholarly attention (ex. Schlipphak \& Trieb 2017). We also include communications in the Parliament when they set the stage for subsequent deliberations in the Council and with the Commission. Finally, to promote data and analytic transparency, we compile these evidentiary materials into a transparency appendix (Trax) that can be consulted to assess contestable evidence-based claims (Moravcsik 2014).

\section{Rhetorics of Inaction in the ROLC}

We begin this assessment with a 'congruence test' (George \& Bennett 2005, pp.181-204): Is there evidence that the jeopardy, perversity, and futility theses pervaded EU deliberations over how to respond to the ROLC? If so, do the rhetorics suffusing communications between the EU institutions and Hungarian Prime Minister and Fidesz party head Viktor Orbán or Polish Law and Justice (PiS) party leader Jarosław Kaczyński meet the conditions theorized in Section III? The available evidence is supportive, pointing to the context and consistent form these rhetorics took throughout the ROLC.

\section{Jeopardy}

Policymaking can be obstructed when recalcitrant actors pay homage to existing norms and policies, and allege proposed changes pose inherent risks (Hirschman 1991, pp.81-132). In the context of the ROLC, this jeopardy thesis tends to take a particular form: EU actions to enforce the rule of law would discriminate against individual member states, thereby jeopardizing the fundamental principle of mutual trust and undermining hard-won policies reliant on intergovernmental dialogue and cooperation.

The jeopardy thesis opens with allegations of hypocrisy so as to seemingly hold the EU accountable to its own claims to institutional legitimacy: Mutual trust and equality amongst states are legalized norms undergirding the EU legal order, intergovernmental dialogue, and Commission enforcement (Manners, 2008; Efrat, 2019). As early as 2011, when the Commission signaled that it might lodge several infringements against Hungary concerning its newly-minted judicial and media reforms, the Hungarian government sent letters to the Commission claiming that 'no part' of its reforms contain 'provisions not found in the legislation of one or more Member States' (Trax.35). Orbán visited the Parliament a year later and similarly framed calls for EU intervention as motivated by 'double standards' posing 'a serious danger, [and] a threat for Europe' because they undermine 'the European way of resolving disputes' (Trax.33, Trax.34). Similar claims would be repeated, almost reflexively, during the Article 7 hearings in the Council: Invoking the Council's publicized commitment to 'non-discrimination and equal treatment of all Member States' in any ROLC deliberations (Trax.32), the Hungarian delegation argued that although its reforms are 'no more stringent than in other Member States' (Trax.20), 'no Member State has been subject to such thorough scrutiny' (Trax.4).

These allegations of hypocrisy were sometimes highly specific and targeted. In a July 2019 speech delivered as Finland - outspokenly in favor of EU action against Hungary - assumed the 
rotating Presidency of the Council, Orbán pondered 'the condition of the rule of law in Hungary if we simply announced the dissolution of the Constitutional Court... This is more or less the situation in Finland... Or just consider the state of the rule of law in Finland, where judges are appointed by the President of the Republic' (Trax.7). Allegations of Finland's 'serious problems' were repeated, almost verbatim, by Orbán's spokesperson in subsequent weeks (Trax.8). And these allegations were plausible prima facie: Finland does not have a Constitutional Court and its judges are appointed as Orbán described. This defense is nonetheless misleading, because it highlights individually reasonable constitutional reforms to distract from 'the horrible way those pieces interact when stitched together' - what Scheppele (2013, p.560) labels the 'Frankenstate' strategy. Yet refuting this rhetoric's flawed comparisons takes time and investigative resources that EU officials often lack. The Polish delegation exploited this fact during multiple Article 7 hearings: Its reforms were 'similar to existing models in other Member States,' and since claims to the contrary 'did not correspond to the data' 'more time... [was] needed to assess their performance' (Trax.19, Trax.6).

The Hungarian and Polish governments proceeded to convert these hypocrisy accusations into jeopardy claims concerning the threat that discriminatory actions posed to the EU's core principles, hard-won transnational policies, and the interests of fellow member states. The Hungarian delegation made this link explicit in a 2018 Council hearing: 'by making unfounded allegations against a Member State/Member States or by referring to the breach of the values of the Union merely due to political/ideological motivation, the unity of the European Union is severely undermined and the confidence among Member States or between Member States and the European institutions is seriously damaged' (Trax.4). The charge that escalating the Article 7 process ' $\mathrm{d}$ [oes] not contribute to the unity of the Union' (Trax.20) mirrored Orbán's prior address to the Parliament in the debate that led to Hungary's Article 7(1) referral: 'What you are doing strikes a blow against both the European Union and the principle of constructive dialogue' (Trax.3). Orbán was hardly alone: the PiS government frequently wields the jeopardy thesis similarly. In a 2019 memo to national delegations in the Council, Poland implied that the Article 7 hearings were being weaponized to undermine a 'positive attitude towards... dialogue' (Trax.2). Poland then lamented that this would lead to the collapse of pre-existing EU policies. For instance, if the Commission pursued infringement for a breach of judicial independence in Poland, it would allegedly jeopardize the most famous EU policy based on mutual trust: The European Arrest Warrant. Selectively citing the ECJ's 2018 Celmer decision, ${ }^{5}$ the Polish delegation argued that 'general doubts about a justice system did not justify' concrete interventions and non-recognition of rulings by the Polish judiciary, for 'otherwise, it might put an end to the EAW' (Trax.6).

There is clear evidence that national governments and EU officials took the jeopardy thesis seriously. The former heeded the Polish and Hungarian governments' cautions that jeopardizing mutual trust would set a dangerous 'precedent' for them, too (Trax.4, Trax.18): As Orbán put it in 2013, all 'member states of the union could find themselves under guardianship in the future' (Trax.34). In the Council, Closa (2020, pp.10-11) found that at least six national governments 'fear[ed] spillover effects' and resisted EU rule of law enforcement precisely in 'anticipated self-defense'. Former MEP Rui Tavares explained that a stubborn commitment to dialogue and mutual trust in the

\footnotetext{
${ }^{5}$ Minister for Justice and Equality v. Celmer (No.1), [2018] IEHC 119.
} 
Council belied reluctance to jeopardize a "'gentlemen's club” agreement... [where] if you don't talk about my case, I don't talk about your case' (Trax.16). jeopardy claims were also plausible or useful to EU officials. The Council wielded it repeatedly to defend its prerogatives, claiming that rule of law interventions by the Commission would 'undermine' the Article 7 procedure and the constructive dialogue it safeguards (Trax.31, Trax.12). Such claims were soon repeated by national governments (ex. Trax.30) and even by newly-elected Commission President Ursula von der Leyen after meeting Orbán in July 2019: 'If we guide debates as sharply as we have done, it contributes to countries and peoples believing that they are being targeted... [since] nobody's perfect' (Trax.17).

Von der Leyen's comments channeled rhetorical appeals by the Hungarian and Polish governments to defend mutual trust and constitutional diversity in the EU against ill-conceived crusades. Hungary's 2018 memo to the Council noted: 'Simply having different rules as regards our constitutional order, does not justify questioning each other's position on the basis of the values of the European Union' (Trax.4). The Polish delegation similarly underscored in a Council hearing that 'the EU respected the different legal systems and constitutional traditions of the Member States' (Trax.6). By appealing to core EU values and the established policies they undergird, the jeopardy thesis flips the script: The true Europeans are in Budapest and Warsaw, whereas the maleficent Europeans are in Brussels and Strasbourg. These claims not only helped to stoke 'fears of spillover' amongst national governments in the Council, but they delivered norm-based justifications for inaction to EU officials committed to safeguarding policies like the EAW and fundamental principles like mutual trust.

\section{Perversity}

If 'progressive' actors push back or ignore claims of jeopardy and hypocrisy, the promoters of inaction can deliver a second retort: the claim that 'well-intentioned' actions would actually produce the opposite effect (Hirschman, 1991, p.12). As Hirschman recognized, efforts to stall policymaking are most likely to succeed when they avoid an 'all-out attack' on a policy or norm by 'endors[ing] it...but then attempt[ing] to demonstrate that the action proposed' would backfire (p.11). In the domain of EU deliberations in the ROLC, the perversity thesis takes the following form: EU efforts to protect democracy and the rule of law will undermine both, since they (a) allegedly infringe upon the democratic mandate of the targeted governments and (b) violate EU law along the way.

The Hungarian and Polish governments habitually delegitimize EU rule of law enforcement efforts by cloaking themselves in the people's will - despite their status as hybrid or competitive authoritarian regimes (Levitsky \& Ziblatt, 2018, p.188; Freedom House, 2020). Initially, these claims appeared credible. When Orbán first started revising the constitution in 2011, Fidesz had just won an overwhelming majority of the seats in Parliament, making its claims that the people elected the Fidesz supermajority for this reason plausible. ${ }^{6}$ Thus even the Hungarian opposition warned that Orbán should 'only be brought down by the Hungarian voters and not by any external influence' (Trax.13). Seven years later when the European Parliament debated whether to activate Article 7(1) against

\footnotetext{
${ }^{6}$ In truth, this majority was obtained by a 'disproportionate election law [that] converted 53 percent of the...vote' to more than $66 \%$ of the Parliament and its public consultations were not conducted within a time frame to impact the final text (Scheppele, 2014, p.61,64,-66).
} 
Hungary (Trax.21), Orbán addressed the assembly claiming he was defending 'the Hungarian people' and 'democracy and freedom' from an undemocratic 'affront.' He challenged: 'You think that you know the needs of the Hungarian people better than the Hungarian people themselves' (Trax.3). Likewise, after the PiS government unexpectedly won the 2015 Polish elections, it acted on its goal of bringing 'Budapest in Warsaw' (Kelemen et al., 2019) by revising the constitution in ways that jeopardized judicial independence. The Commission initiated a dialogue under the Rule of Law Framework, and Poland's Minister of Justice quipped that it was 'attempt[ing] to exert pressure upon the democratically elected Parliament and Government of the sovereign Republic of Poland'; PiS not only 'enjoys an undisputed democratic mandate', but it had merely taken 'remedial actions to reinstate pluralism in the Constitutional Court' (Trax.1). As we will see, invoking the election results made this argument plausible, and EU officials consistently worried that they 'shouldn't use any tough method which would turn the Polish population against Europe' (Trax.15). ${ }^{7}$ This credible risk helped legitimate delayed enforcement, and it was only two years later, once Poland proved unwilling to dialogue with the Commission, that the latter invoked Article 7(1) (Trax.22; Scheppele et al. 2021, p.37).

Beyond claiming a democratic mandate, Hungarian and Polish officials also put the EU on the defensive by alleging that its attempts to safeguard the rule of law would, perversely, violate the EU's rules of law. As Parliament adopted the report triggering an Article 7(1) referral, Orbán cautioned that such an act constituted 'a treaty violation' (Trax.3). In subsequent Council hearings, the Hungarian delegation elaborated this claim, arguing that Parliament 'breached Article 354 (4) TFEU, as well as Article 178 (3) of its own Rules of Procedure by excluding abstentions when calculating the votes cast' (Trax.4); in any case, 'the procedure pursuant to Article 7(1) lacked a legal basis' (Trax.20). And again when the Finnish Council presidency promised to place the rule of law to the top of the agenda, Hungary rebutted that it was 'not in line with the content and legal constraints of the Semester' (Trax.5). All of these efforts legitimize EU actors regularly falling back on dialogue over active enforcement, until and unless recalcitrant governments prove manifestly unwilling to engage (Scheppele et al, 2021, p.37). ${ }^{8}$

A complementary strategy is to weaponize the Council and Commission's stated commitment that any enforcement action be 'evidence-based' in order to be legally sound (Trax.32). Having eliminated most checks on their domestic political powers, Orbán and Kaczyński could pass and amend legislation at will, flooding European policymakers with novel 'facts' and stalling decisionmaking as they struggled to keep up. Between 2010 and 2013, for instance, the Fidesz parliamentary supermajority in Hungary scrapped its constitution and passed over 400 laws - oftentimes without deliberation (Scheppele, 2014). Many such laws were tailored to enable what Orbán referred to as the 'dance of the peacock:' embedding extreme provisions within legislation 'designed to be jettisoned' and framed as evolving 'compromises' with the EU (Trax.36). This strategy can work in tandem with the jeopardy thesis by exalting the virtues of dialogue while delegitimizing more forceful EU action as premised on 'old facts.' For instance, when the Parliament debated the Commission's first rule of law

\footnotetext{
7 Despite the fact that EU popularity among Hungarian and Polish citizens remains among the highest in all Europe (Scheppele \& Halmai, 2019).

8 A conclusion rebutted by the Polish and Hungarian governments by repeatedly invoking their commitment to dialogue (Trax.2, Trax.6, Trax.20).
} 
infringements in January 2012, Orbán deplored having to 'corre[ct] every one of the unfortunately numerous factual mistakes that were made,' advising: 'please be so kind as to read [the revised Hungarian] constitution' (Trax.33). And after the Parliament triggered Article 7(1), the Hungarian delegation sought to rally the Council against MEPs by deploring the 'limited possibility to the Hungarian Government to provide full information,' charging that the resolution's factual claims 'have become obsolete' (Trax.4). This strategy derailed the first Council Article 7 hearing on Hungary's referral in September 2019. The Polish government proceeded similarly in its interactions with EU officials. For instance, in a December 2015 letter to Commission Vice-President Timmermans, Poland's Justice Minister lamented his 'lack of knowledge about the factual developments related to the Constitutional Court.' (Trax.1). The Polish delegation repeated these claims in the Council, alleging that any move beyond Article 7 dialogue 'would be premature' and unsubstantiated (Trax.18, Trax.6).

Like the jeopardy thesis, EU officials had rational reasons to take the perversity thesis seriously. First, the Commission clearly feared that its interventions would be perceived as illegitimate and trigger a democratic backlash, invoking the 2000 'Haider affair' as precedent. In that instance, EU states suspended bilateral diplomatic relations with Austria after the far-right Freedom Party came to power in coalition, attracting a popular backlash (Schlipphak \& Trieb 2017). While this experience was implemented outside the EU's treaty framework, it lent credibility to Hungary and Poland's warnings that the people would rally behind their governments. Congruent with our theoretical expectations, the jeopardy thesis tapped into historical precedents and exploited uncertainty to appeal to progressive yet risk-averse actors with sincere concerns about their own legitimacy (Schimmelfennig, 2001, p. 48). Even Timmermans - the Commission's most forceful advocate for action - acknowledged that 'the case of Austria... weakened the EU's capacity to react in such a case. It was a political response which completely backfired... and since then Member States have been reluctant to take issue with other Member States on this basis. That is one of the challenges I personally will have to face' (Trax.14). Indeed, Closa (2019, pp.708-709)'s interviews with Commission officials confirm their perception that 'Orbán had skillfully exploited infringement procedures to his own advantage,' as well as their fear that enforcement would have 'backfiring effects' and 'pollute a state's relations with the EU'.

The perversity thesis also suited the Council's desire to avoid being sidestepped by the Commission (Kochenov \& Pech, 2015). After the Commission announced the creation of the Rule of Law Mechanism in 2014, the Council Legal Service's ('CLS') review claimed that the Mechanism violated EU law because it 'is not compatible with the principle of conferral' (Trax.31). And when in 2018 the Commission proposed withholding EU funds to member states undermining the rule of law, the CLS once again rebutted that the Commission's proposal breached EU law because it failed to 'establish a genuine link between the measures being adopted and the protection of the budget' (Trax.12).

By demanding that EU decision-making be a model of legal proceduralism, Orbán, Kaczyński and their allies in the Council tap into the intuitive logic that the EU has to meticulously abide by rule of law principles for any supranational intervention to be perceived as legitimate and avoid the democratic backlash the Commission fears. Combined with the jeopardy thesis, perversity claims thus turn democracy and rule of law norms against the EU itself. 


\section{Futility}

While the first two rhetorical strategies 'take an extremely serious view of the...policies' they rebuke, the final rhetoric of inaction pervading the EU's discursive interactions in the ROLC simply proclaims 'attempts at change as inept' (Hirschman 1991, p.79). Under this futility thesis, the EU lacks the competences and appropriate tools to effectively intervene in Hungary and Poland to safeguard the rule of law.

Users of the futility argument rarely claim that the EU has no tools for rule of law enforcement, for this rhetorical strategy would lack face validity (ex., Hillion, 2016; Jakab \& Kochenov, 2017). Rather, they claim that the EU's tools are ill-suited for the task at hand, thus rendering them 'all but unusable' (Mueller, 2013, p.146). What is indeed noteworthy is that the futility thesis is introduced for the ROLC by supranational 'progressives' - it was pioneered by European Commission President José Manuel Barroso in his 2012 State of the Union address. The constitutional breakdown of Hungary, Barroso argued, 'revealed limits of our institutional arrangements. We need a better developed set of instruments - not just the alternative between the "soft power" of political persuasion and the "nuclear option" of article 7 of the Treaty' (Trax.9). Barroso's conflation of Article 7 with nuclear weapons became commonplace and was reiterated by the Commission Legal Service, which conceded that 'a systemic threat to the rule of law in Member States cannot...be effectively addressed by the instruments currently existing at the level of the Union' (Trax.10).

Once again, the Council latched onto the Commission's futility claims for its own purposes. In particular, the CLS pioneered the claim that the EU lacked the competence to create new rule of law enforcement tools beyond the Article 7 procedure, and it repeated it so consistently that it ricocheted back to the Commission, bolstering its own reluctance. Every time the Commission timidly sought to act, it was met with futility claims from the CLS. When the Commission introduced its Rule of Law Mechanism, the CLS proclaimed that not only was member state pressure and dialogue-centric 'peer review' the only existing tool 'compatible with the Treaties,' but 'there is no legal basis in the Treaties empowering the institutions to create a new supervision mechanism of the respect of the rule of law by the Member States' (Trax.31). Subsequently, upon proposing a rule of law conditionality regulation for the EU budget in 2018, the CLS concurred with member state 'delegations [that] raised various issues of compatibility with the Treaties of the Commission proposal', suggesting that the Commission lacked the competence to act (Trax.12). Unsurprisingly, the Commission became obsessed with certifying that any potential enforcement action was within its competences and had an incontrovertible legal basis (Closa 2019, p.709).

Futility claims were not only picked up by lawyers in the Council: They diffused far and wide in EU circles where policymakers are habituated to favoring scalpels over clubs. As Kochenov (2017, p.2) laments, 'the claims that little to nothing can be done under the current legal framework... are heard with remarkable regularity' in Brussels. The view is not only ensconced in a legalistic claim of lack of competences; its persuasive effect is equally ground in many EU officials' self-defeated view of political reality. In confidential interviews, Commission civil servants conceded to Closa (2019, p.709) that because the EU is not 'a federal state,' 'the Commission has limits to what it can do... and we cannot change a government, we cannot change Mr. Orban'.

The Council's insistence that the EU lacked the competence to create rule of law enforcement tools beyond the 'nuclear' Article 7 procedure, combined with Commission officials' self-professions 
of the limits to their political power, caused the EU to twist itself into a rhetorical bind: If the EU could neither rely on informal pressure (for it is too weak), nor on Article 7 (for it is too strong), then rule of law enforcement was doomed to failure. Meanwhile, the Hungarian and Polish governments bought time to hollow out the rule of law at home even as they occasionally joined in reminding the EU of the limits to its competences. Orbán for one emphasized that if Parliament triggered Article $7(1)$, it would 'overste[p] the limits on spheres of competence' (Trax.3). Used in this manner, EU officials' futility arguments complemented the jeopardy and perversity arguments that became the trademark justification for inaction of the Hungarian and Polish governments.

\section{Not All Rhetoric Goes: The Failure of Populist and Partisan Rhetorics of Inaction}

In uncovering evidence that the jeopardy, perversity, and futility theses entrenched themselves in EU deliberations during the ROLC, we identified a congruence between the empirical evidence and the three conditions posited by our theory of rhetorics of inaction. Do these rhetorics of inaction have the same impact when our theorized conditions are not met? In this section, we uncover evidence that overtly populist and partisan rhetorical affronts on EU action are not only ineffective, but they can actually provoke the EU to act. For reasons of space, we limit our examples to two.

First, consider the events leading to Fidesz' suspension from the European People's Party (EPP). In early 2019, Fidesz launched a media blitz to rally domestic support for its 'Stop Brussels' campaign, alleging that EPP-affiliated Commission President Juncker was part of a conspiracy alongside philanthropist George Soros to flood Hungary with asylum seekers and 'weaken member states' rights to protect their own borders': 'You have a right to know what Brussels is trying to do' to 'fundamentally endange[r] Hungary's safety', read a poster featuring Juncker and Soros (Trax.28). This domestically-oriented message did little to conceal base motives behind norm-based arguments: It weaponized xenophobia and antisemitism against the EU's fundamental values, and by targeting Juncker it made no attempt to appeal to the Commission's interests. The EU's response was swift. The Commission issued an 'unusually forceful rebuttal' (Trax.28), while 'the Swedish Moderate Party and quickly a dozen other EPP member parties [called] for a vote on expelling Fidesz from the EPP' (Kelemen 2020, p.488). Even if Fidesz's suspension was labeled a 'ruse' by some (Ibid), it ultimately proved to be populist rhetoric - not Fidesz' authoritarian policies - that provoked a tepid sanction from the EPP. This outcome fits a broader pattern. In September 2018, Kaczyński lambasted EU enforcement efforts in a speech during a PiS convention, claiming that Poland was being infected by social diseases' and 'attacked' in an EU campaign to 'demean... Poland' (Trax.26). Shortly thereafter European Council President Donald Tusk abandoned 'years of treading carefully' in the ROLC by holding his first rally in Poland since leaving for Brussels in 2014, calling on the Polish people to 'defeat today's Bolsheviks' (Trax.27). Kaczyński's rhetorical affronts proved a bridge too far.

Another example concerns the failed 2019 campaign for the Commission Presidency by the Parliament's EPP leader, Manfred Weber. Weber's partisan coddling of the Hungarian government surely delayed the Parliament's efforts to activate Article 7 (Kelemen 2020; Closa 2020), but it came with self-defeating rhetorical politics. Rather than concealing partisan interests behind a norm-based argument, Weber frequently defended Hungary in partisan terms. For instance, Weber rallied opposition to the Parliament's Tavares Report by claiming that 'the Report is a wish list of the 
European leftist parties who aim to impose their own political agenda on Hungary... their continuous attempts to condemn EPP-led governments is biased and politically motivated' (Trax.24). Weber's campaign for the Commission Presidency consequently 'faced a barrage of criticism on the campaign trail regarding his close relationship with Orban' (Trax.29). Despite being the Spitzenkandidat for the largest Parliamentary group and a last-minute campaign pivot to tougher rhetoric, Weber's candidacy collapsed (Kelemen 2020, pp.488-489). Partisan coddling can backfire when it fails to maintain a more consistent and principled rhetorical veneer.

The foregoing evidence bolsters support for our theoretical expectation that rhetorics of inaction are unlikely to succeed if they attack EU norms and values head-on, make no attempt to appeal to actors with heterogenous preferences, or are deployed too cynically or inconsistently.

\section{Conclusions and Future Research Paths}

The EU's ROLC highlights that political crises do not always beget institutional 'completion.' This 'failure to fail forward' has gone hand-in-hand with the proliferation in EU deliberations of what we call the 'rhetoric of inaction.' Even EU officials publicly committed to rule of law enforcement have found these rhetorics persuasive enough to abate their will to act or useful enough to legitimate their self-interest not to act. In fact, these rhetorics have even begun to take root in academic circles, especially amongst prominent EU legal scholars (Kelemen et al., 2019). The more these arguments are parroted by well-meaning actors, the more credible they become, and the harder action is to justify. To be sure, crisis-propelled policymaking is no panacea (Jones et al. 2016), and EU efforts to defend the rule of law are plagued by significant institutional hurdles and divergent preferences. But the price of passivity is that the crisis metastasizes, leaving the rule of law gutted in the aftermath.

Indeed, even as rhetorics of inaction justify stasis, the costs of not addressing a festering crisis can become severe. For instance, the ROLC poses a fundamental threat to EU's global status as a rule of law and democracy promoter. In Timmermans' words, 'the rule of law... [is] a principle that guides both our internal and external actions' (Magen, 2016, p. 1057). Failures to address the rule of law crisis at home will weaken the EU's standing and capacity to promote the rule of law abroad. Equally absent from EU deliberations in the ROLC is a realization that rhetorics of inaction are contradictory if deployed in tandem. It is 'difficult to argue at one and the same time that a certain [policy action] will be sharply counterproductive... and that it will have no effect at all' (Hirschman 1991, p.45). In this light, national governments and EU officials committed to act would be well-advised to develop counter-rhetorics that underscore the mounting costs of inaction and the inherent inconsistencies of rhetorics of inaction - a classic move to undermine the persuasiveness of justificatory arguments (Elster 1999; Schimmelfennig 2001).

This article also serves as a prolegomenon for future research. First, additional comparative analyses could assess whether the jeopardy, perversity, and futility theses have pervaded the EU's (non-)responses to other crises - such as the Schengen crisis where 'states...failed to agree on substantial integration process' (Schimmelfennig 2018, p.970). Second, while we follow Schimmelfennig (2001, p.66) by analyzing the strategic use of rhetoric rather than 'whether or not political actors really mean what they say,' discursive institutionalists make the stronger claim that rhetoric can 'unfix preferences' (Schmidt 2008, pp.313-317). Additional research could probe if under 
certain conditions rhetorics of inaction can provoke political elites to go so far as to reorient their base interests against deeper integration. Finally, prior research implies that when crises are broadly acknowledged as endogenous to incomplete or suboptimal EU rules, policymakers will be more open to pro-integration rhetoric (Schmidt 2013, p.1033). We suspect that rhetorics of inaction may have gained particular currency precisely amongst policymakers who doubted that the ROLC constituted a genuinely European crisis in the first place. If this is true, then political elites will only favor rhetorical justifications for ingenuity and institutional expansion to the extent that they can tie a crisis' origins directly to the EU's institutional architecture. Future research could investigate if under such conditions, policymakers are better able to resist the allure of futility claims and to eschew succumbing to national governments' allegations of perversity and hypocrisy. 


\section{References}

Bakke, E., \& Sitter, N. (2020). The EU’s Enfants Terribles. Perspectives on Politics, 1-16.

Blauberger, M., \& Kelemen, R. D. (2017). Can Courts Rescue National Democracy? Journal of European Public Policy 24 (3), 321-336.

Blauberger, M., \& van Huellen, V. (2020). Conditionality of EU funds. Journal of European Integration, 1-16.

Closa, C. (2019). The Politics of Guarding the Treaties. Journal of European Public Policy 26 (5), 696-716.

Closa, C. (2020). Institutional logics and the EU's limited sanctioning capacity under Article 7 TEU. International Political Science Review, 1-15.

Dawson, James, and Sean Hanley. (2019). Foreground Liberalism, Background Nationalism. Journal of Common Market Studies 57 (4): 710-728.

Efrat, A. (2019). Assessing Mutual Trust Among EU Members. Journal of European Public Policy 26 (5), 656-675.

Elster, J. (1999). Arguing and bargaining in two constituent assemblies. University of Pennsylvania Journal of Constitutional law 2, 345-421.

Freedom House. (2020). Nations in Transit 2020: Dropping the Democratic Façade. Washington, DC.

Hillion, C. (2016). Overseeing the rule of law in the European Union. SIEPS European Policy Analysis 1,1-16.

Hirschman, A. (1991). The Rhetoric of Reaction. Harvard University Press.

Jakab, A., \& Kochenov, D. (2017). The Enforcement of EU Law and Values. Oxford University Press.

Jones, E., Kelemen, R. D., \& Meunier, S. (2016). Failing Forward? Comparative Political Studies 49 (7), 1010-1034.

Kelemen, R. D. (2019). Is Differentiation Possible in Rule of Law? Comparative European Politics 17 (2), 246-260.

Kelemen, R. D. (2020). The European Union' Authoritarian Equilibrium. Journal of European Public Policy 27 (3), 481-499.

Kelemen, R. D., Pavone, T., \& Emmons, C. (2019) The Perils of Passivity in the Rule of Law Crisis. Verfassungsblog, November 19.

Kochenov, D. (2017). Busting the Myths Nuclear. EUI Working Paper No. LAW 2017/10, 1-21. 
Kochenov, D., \& Pech, L. (2015). Monitoring and Enforcement of the Rule of Law in the EU. European Constitutional Law Review 11, 512-540.

Kochenov, D., \& Bard, P. (2019). The Last Soldier Standing? In European Yearbook of Constitutional Law 2019, Ballin et al. (eds), 243-287.

Levitsky, S., \& Ziblatt, D. (2018). How Democracies Die. Penguin.

Levy, J. (2008). Case Studies. Conflict Management and Peace Science 25, 1-18.

Magen, A. (2016). Cracks in the Foundations. Journal of Common Market Studies 54 (5), 1050-1061.

Manners, I. (2008). The Normative Ethics of the European Union. International Affairs 84 (1), 45-60.

March, J., \& Olsen, J. (1998). The Institutional Dynamics of International Political Orders. International Organization 52 (4), 943-969.

Moravcsik, A. (2014). Transparency. PS: Political Science and Politics 47 (1), 48-53.

Mueller, J.-W. (2013). Defending Democracy Within the EU. Journal of Democracy 24 (2), 138-149.

Neyer, J. (2003). Discourse and Order in the EU. Journal of Common Market Studies 41 (4), 687-706.

OSCE. (2018). Hungary: Parliamentary Elections, 8 April 2018: https://www.osce.org/files/f/documents/0/9/385959.pdf

Risse, T. (2000). Let's Argue! International Organization 54 (1), 1-39.

Sadurski, W. (2010). Adding a Bite to a Bark? Sydney Law School Research Paper No. 10/01.

Sadurski, W. (2019). Poland's Constitutional Breakdown. Oxford University Press.

Scheppele, K. L. (2013). The Rule of Law and the Frankenstate. Governance 26(4), 559-562.

Scheppele, K. L. (2014). Constitutional Coups and Judicial Review. Transnational Law and Contemporary Problems 23(1), 51-118.

Scheppele, K. L. (2018). Autocratic Legalism. University of Chicago Law Review 85, 545-584.

Scheppele, K. L., Pech, L., \& Kelemen, R. D. (2018). Never Missing an Opportunity to Miss an Opportunity. Verfassungsblog, November 12.

Scheppele, K. L., \& Halmai, G. (2019). The Tyranny of Values or the Tyranny of One-Party States? Verfassungsblog, November 25.

Scheppele, K. L., Kochenov, D., \& Grabowska-Moroz, B. (2021). EU Values are Law, After All. Yearbook of European law, 1-121. 
Schimmelfennig, F. (2001). The Community Trap. International Organization 55 (1), 47-80.

Schimmelfennig, F. (2017). Theorising Crises in European Integration. In The European Union in Crisis, Dinan et al. (eds). Palgrave Macmillan.

Schlipphak, B., \& Treib, O. (2017). Playing the blame game on Brussels. Journal of European Public Policy 24 (3), 352-365.

Schmidt, V. (2008). Discursive Institutionalism. Annual Reviews of Political Science 11, 303-326.

Schmidt, V. (2013). Speaking to the Markets or to the People? British Journal of Politics \& International Relations 16, 188-209.

Sedelmeier, U. (2017). Political safeguards against democratic backsliding in the EU. Journal of European Public Policy 24 (3), 337-351.

Soifer, H. (2012). The Causal Logic of Critical Junctures. Comparative Political Studies 45 (12), 1572-1597.

Soyaltin-Colella, D. (2020). The Eu's 'Actions-Without-Sanctions'? European Politics and Society, 1-17.

Uitz, R. (2019). The Perils of Defending the Rule of Law Through Dialogue. European Constitutional Law Review 15, 1-16.

Ulbert, C., \& Risse, T. (2005). Deliberately Changing the Discourse. Acta Politica 40, 351-367. 
TRANSPARENCY APPENDIX (Trax) for "The Rhetoric of Inaction: Failing to Fail Forward in the Rule of Law Crisis"

Table 1: Table of contents of evidence included in the Transparency Appendix (Trax)

\begin{tabular}{|c|c|c|c|c|}
\hline Date & Speaker & Title / description & $\begin{array}{c}\text { Trax } \\
\#\end{array}$ & $\begin{array}{c}\text { Link/place of } \\
\text { publication }\end{array}$ \\
\hline $12 / 29 / 10$ & $\begin{array}{l}\text { Tibor Navracsics } \\
\text { (Hungarian } \\
\text { Deputy Prime } \\
\text { Minister; quoted) }\end{array}$ & $\begin{array}{l}\text { Letter from Commission Vice President } \\
\text { Neelie Kroes to the Hungarian Deputy Prime } \\
\text { Minister Tibor Navracsics dated } 17 \text { January } \\
\text { 2012, quoting letter from Prime Minister } \\
\text { Tibor Navrocics to Commissioner Kroes } \\
\text { dated } 29 \text { December } 2010\end{array}$ & 35 & $\begin{array}{l}\frac{\text { https://www.ft.com/ }}{\text { content/5a8db263- }} \\
\frac{\text { 2852-37d5-a769- }}{\text { 75aeae2e23ee }}\end{array}$ \\
\hline $9 / 12 / 12$ & $\begin{array}{l}\text { Commission } \\
\text { President José } \\
\text { Manuel Barroso }\end{array}$ & $\begin{array}{l}\text { State of the Union speech by European } \\
\text { Commission President José Manuel Barroso }\end{array}$ & 9 & $\begin{array}{l}\text { https://europa.eu/rap } \\
\text { id/press- } \\
\text { release SPEECH-12- } \\
596 \text { en.htm }\end{array}$ \\
\hline $7 / 11 / 13$ & $\begin{array}{l}\text { Former } \\
\text { Hungarian Prime } \\
\text { Minister Gordon } \\
\text { Bajnai (quoted) }\end{array}$ & $\begin{array}{l}\text { Buckley, Neil, Fontanella-Khan, James, and } \\
\text { Kester Eddy. 2013. " EU weighs fines for } \\
\text { democratic breaches after Hungary tensions." } \\
\text { Financial Times. }\end{array}$ & 13 & $\begin{array}{l}\frac{\text { https://www.ft.com/ }}{\text { content/3901b64c- }} \\
\frac{\text { ea12-11e2-913c- }}{\underline{00144 \text { feabdc0 }}} \\
\end{array}$ \\
\hline $9 / 4 / 13$ & $\begin{array}{l}\text { Commission } \\
\text { Vice President } \\
\text { Viviane Reding }\end{array}$ & $\begin{array}{l}\text { "The EU and the Rule of Law - What's } \\
\text { Next?" Speech/12/379 }\end{array}$ & 25 & $\begin{array}{l}\frac{\text { https://ec.europa.eu/ }}{\text { commission/presscor }} \\
\text { ner/detail/en/SPEEC } \\
\text { H } 13677 \\
\end{array}$ \\
\hline $9 / 11 / 13$ & $\begin{array}{l}\text { Commission } \\
\text { President José } \\
\text { Manuel Barroso }\end{array}$ & $\begin{array}{l}\text { State of the Union Address by European } \\
\text { Commission President José Manuel Barroso. }\end{array}$ & 23 & $\begin{array}{l}\underline{\underline{\text { https://ec.europa.eu/ }}} \\
\text { commission/presscor } \\
\text { ner/detail/en/SPEEC } \\
\underline{\text { H } 13684} \\
\end{array}$ \\
\hline $7 / 3 / 13$ & $\begin{array}{l}\text { European } \\
\text { People's Party } \\
\text { (EPP) }\end{array}$ & $\begin{array}{l}\text { EPP Press Release, "EP Report on Hungary: } \\
\text { EPP Group Rejects the Use of Double } \\
\text { Standards." }\end{array}$ & 24 & $\begin{array}{l}\frac{\text { https://www.eppgrou }}{\text { p.eu/newsroom/news }} \\
\text { Lepp-group-rejects- } \\
\text { the-use-of-double- } \\
\text { standards }\end{array}$ \\
\hline $3 / 11 / 14$ & $\begin{array}{l}\text { European } \\
\text { Commission }\end{array}$ & $\begin{array}{l}\text { Communication from the Commission to the } \\
\text { European Parliament and the Council on a } \\
\text { New EU Framework to Strengthen the Rule } \\
\text { of Law. }\end{array}$ & 10 & $\begin{array}{l}\text { https://eur- } \\
\text { lex.europa.eu/legal- } \\
\text { content/EN/TXT/P } \\
\text { DF/?uri=CELEX:520 } \\
\text { 14DC0158\&from=E } \\
\text { N }\end{array}$ \\
\hline $8 / 31 / 15$ & $\begin{array}{l}\text { Commission } \\
\text { Vice President } \\
\text { Frans } \\
\text { Timmermans }\end{array}$ & $\begin{array}{l}\text { Frans Timmermans. Keynote speech at } \\
\text { Conference on the Rule of Law, Tilburg } \\
\text { University }\end{array}$ & 14 & $\begin{array}{l}\underline{\text { https://web.archive.o }} \\
\mathrm{rg} / \text { web/20171004031 } \\
216 / \mathrm{https} / / \text { ec.europ } \\
\text { a.eu/commission/co } \\
\text { mmissioners/2014- } \\
\text { 2019/timmermans/an } \\
\text { nouncements/europea } \\
\text { n-union-and-rule-law- } \\
\text { keynote-speech- } \\
\text { conference-rule-law- } \\
\text { tilburg-university-31- } \\
\text { august-2015 en }\end{array}$ \\
\hline
\end{tabular}




\begin{tabular}{|c|c|c|c|c|}
\hline Date & Speaker & Title / description & $\begin{array}{c}\text { Trax } \\
\#\end{array}$ & $\begin{array}{l}\text { Link/place of } \\
\text { publication }\end{array}$ \\
\hline $1 / 11 / 16$ & $\begin{array}{l}\text { Polish } \\
\text { Government }\end{array}$ & $\begin{array}{l}\text { Letter from Polish Ministry of Justice to EU } \\
\text { Commission VP Timmermans. }\end{array}$ & 1 & $\begin{array}{l}\frac{\text { https://static1.squares }}{\text { pace.com/static/5abb }} \\
\text { 53e6372b9691939ac57} \\
\frac{7 / \mathrm{t} / 5 \mathrm{c} 78 \mathrm{e} 3437817 \mathrm{f} 7 \mathrm{e}}{6 \mathrm{~d} 9954860 / 15514263} \\
\frac{\text { 88869/2016Jan11+Po }}{\text { land+Letter+to+Tim }} \\
\underline{\text { mermans+4p+copy.p }}\end{array}$ \\
\hline $3 / 10 / 16$ & $\begin{array}{l}\text { MEP Rui } \\
\text { Tavares (quoted) }\end{array}$ & $\begin{array}{l}\text { Zalan, Eszter. 2016. "Can Europe Stand Up } \\
\text { to Its Own Strongmen?" Foreign Policy. }\end{array}$ & 16 & $\begin{array}{l}\frac{\text { https://foreignpolicy- }}{\text { com.ezproxy.uio.no/2 }} \\
016 / 03 / 10 / \text { can- } \\
\text { europe-stand-up-to- } \\
\text { its-own-strongmen/ }\end{array}$ \\
\hline $5 / 25 / 16$ & $\begin{array}{l}\text { Commission } \\
\text { Vice President } \\
\text { Frans } \\
\text { Timmermans } \\
\text { (quoted) }\end{array}$ & $\begin{array}{l}\text { De la Baume, Maia. 2016. "Brussels Struggles } \\
\text { with its Poland Problem." Politico, May } 25 .\end{array}$ & 15 & $\begin{array}{l}\text { https://www-politico- } \\
\text { eu.ezproxy.uio.no/arti } \\
\text { cle/pis-commission- } \\
\text { human-rights-warsaw- } \\
\text { europe-struggles-to- } \\
\text { solve-its-poland- } \\
\text { problem/ }\end{array}$ \\
\hline $6 / 26 / 18$ & $\begin{array}{l}\text { European } \\
\text { Council }\end{array}$ & $\begin{array}{l}\text { August 8, } 2018 \text { Report of the hearing held by } \\
\text { the Council on } 26 \text { June } 2018 \text { Re-Rule of Law } \\
\text { in Poland / Article 7(1) TEU Reasoned } \\
\text { Proposal. }\end{array}$ & 18 & $\begin{array}{l}\frac{\text { http://www.statewatc }}{\text { h.org/news/2018/aug }} \\
\text { Leu-council-rule- } \\
\text { ofLaw-poland-10906- } \\
\text { 18.pdf }\end{array}$ \\
\hline $7 / 19 / 17$ & $\begin{array}{l}\text { Commission } \\
\text { Vice President } \\
\text { Frans } \\
\text { Timmermans }\end{array}$ & $\begin{array}{l}\text { Opening remarks of First Vice-President } \\
\text { Frans Timmermans, "College readout on } \\
\text { grave concerns about the clear risks for } \\
\text { independence of the judiciary in Poland." }\end{array}$ & 11 & $\begin{array}{l}\text { http://europa.eu/rapi } \\
\text { d/press- } \\
\text { release SPEECH-17- } \\
2084 \text { en.pdf } \\
\end{array}$ \\
\hline $12 / 11 / 18$ & $\begin{array}{l}\text { European } \\
\text { Council }\end{array}$ & $\begin{array}{l}\text { December 20, } 2018 \text { report of the hearing held } \\
\text { by the Council on } 11 \text { December } 2017 \text { Re- } \\
\text { Rule of Law in Poland / Article 7(1) TEU } \\
\text { Reasoned Proposal. }\end{array}$ & 19 & 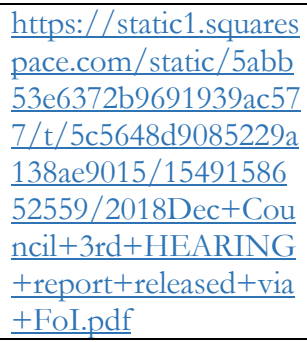 \\
\hline $12 / 20 / 17$ & $\begin{array}{l}\text { European } \\
\text { Commission }\end{array}$ & $\begin{array}{l}\text { Proposal for a Council Decision on the } \\
\text { determination of a clear risk of a serious } \\
\text { breach by the Republic of Poland of the rule } \\
\text { of law COM/2017/0835 final. }\end{array}$ & 22 & $\begin{array}{l}\text { https://eur- } \\
\text { lex.europa.eu/legal- } \\
\text { content/EN/TXT/?u } \\
\text { ri=celex:52017PC0835 } \\
\end{array}$ \\
\hline $9 / 11 / 18$ & $\begin{array}{l}\text { Hungarian Prime } \\
\text { Minister Viktor } \\
\text { Orban }\end{array}$ & $\begin{array}{l}\text { Address by Prime Minister Viktor Orbán in } \\
\text { the debate on the so-called "Sargentini } \\
\text { Report." }\end{array}$ & 3 & $\begin{array}{l}\text { https://www.korman } \\
\text { y.hu/en/the-prime- } \\
\text { minister/the-prime- } \\
\text { minister-s- } \\
\text { speeches/address-by- } \\
\text { prime-minister-viktor- } \\
\text { orban-in-the-debate- } \\
\text { on-the-so-called- } \\
\text { sargentini-report }\end{array}$ \\
\hline
\end{tabular}




\begin{tabular}{|c|c|c|c|c|}
\hline Date & Speaker & Title / description & $\begin{array}{c}\text { Trax } \\
\#\end{array}$ & $\begin{array}{c}\text { Link/place of } \\
\text { publication }\end{array}$ \\
\hline $9 / 12 / 18$ & $\begin{array}{l}\text { European } \\
\text { Parliament }\end{array}$ & $\begin{array}{l}\text { European Parliament Resolution of } 12 \\
\text { September } 2018 \text { on a proposal calling on the } \\
\text { Council to determine, pursuant to Article } 7(1) \\
\text { of the Treaty on European Union, the } \\
\text { existence of a clear risk of a serious breach by } \\
\text { Hungary of the values on which the Union is } \\
\text { founded (P8_TA }(2018) 0340) \text {. }\end{array}$ & 21 & $\begin{array}{l}\frac{\text { http://www.europarl. }}{\text { europa.eu/doceo/doc }} \\
\underline{\underline{\text { ument/TA-8-2018- }}} \\
\underline{0340 \text { EN.html }}\end{array}$ \\
\hline $9 / 18 / 18$ & $\begin{array}{l}\text { Council of the } \\
\text { European Union }\end{array}$ & $\begin{array}{l}\text { "Rule of Law in Poland / Article 7(1) TEU } \\
\text { Reasoned Proposal." November 5, } 2018 \\
\text { Report of the hearing held by the Council on } \\
\text { 18 September } 2018 .\end{array}$ & 6 & 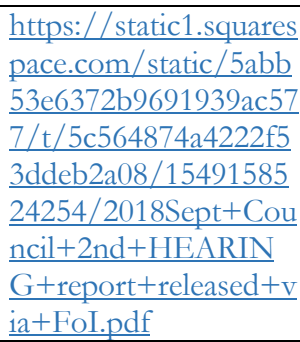 \\
\hline $11 / 12 / 18$ & $\begin{array}{l}\text { Council Legal } \\
\text { Service (quoted) }\end{array}$ & $\begin{array}{l}\text { October } 25,2018 \text { Opinion of the Legal } \\
\text { Service of the European Council, Re- } \\
\text { Proposal for a Regulation of the European } \\
\text { Parliament and of the Council on the } \\
\text { protection of the Union's budget in case of } \\
\text { generalized deficiencies as regards the rule of } \\
\text { law in the Member States }\end{array}$ & 12 & $\frac{\underline{\text { https://doi.org } / 10.17}}{\underline{\underline{176 / 20181115-}}}$ \\
\hline $11 / 13 / 18$ & $\begin{array}{l}\text { Hungarian } \\
\text { Government }\end{array}$ & $\begin{array}{l}\text { "Information on the Resolution on the } \\
\text { situation in Hungary adopted by the } \\
\text { European Parliament on } 12 \text { September } \\
\text { 2018." memo by the Hungarian delegation to } \\
\text { the European Council }\end{array}$ & 4 & 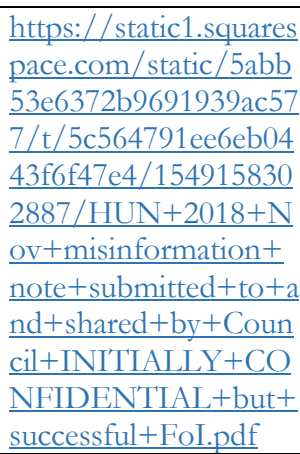 \\
\hline $1 / 28 / 19$ & $\begin{array}{l}\text { Polish } \\
\text { Government }\end{array}$ & $\begin{array}{l}\text { "Summary of actions undertaken by Poland } \\
\text { in order to address European Commission's } \\
\text { recommendations concerning the reform of } \\
\text { the Polish judiciary." Internal message from } \\
\text { the Polish Government to the European } \\
\text { Council. }\end{array}$ & 2 & 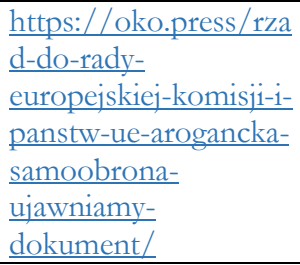 \\
\hline 7/11/19 & $\begin{array}{l}\text { Hungarian } \\
\text { Government }\end{array}$ & $\begin{array}{l}\text { Declaration of the Hungarian Government } \\
\text { on the June 6, } 2019 \text { Council } \\
\text { Recommendation on the } 2019 \text { National } \\
\text { Reform Programme of Hungary and } \\
\text { delivering a Council opinion on the } 2019 \\
\text { Convergence Programme of Hungary. }\end{array}$ & 5 & $\frac{\underline{\text { https://twitter.com/P }}}{\underline{\underline{\text { rofPech/status } / 11492}}}$ \\
\hline $7 / 27 / 19$ & $\begin{array}{l}\text { Hungarian Prime } \\
\text { Minister Viktor } \\
\text { Orban }\end{array}$ & $\begin{array}{l}\text { Prime Minister Viktor Orbán’s speech at the } \\
\text { 30th Bálványos Summer Open University } \\
\text { and Student Camp }\end{array}$ & 7 & $\begin{array}{l}\text { http://abouthungary. } \\
\text { hu/speeches-and- } \\
\text { remarks/prime- } \\
\text { minister-viktor- } \\
\text { orbans-speech-at-the- } \\
\text { 30th-balvanyos- }\end{array}$ \\
\hline
\end{tabular}




\begin{tabular}{|c|c|c|c|c|}
\hline Date & Speaker & Title / description & $\begin{array}{c}\text { Trax } \\
\#\end{array}$ & $\begin{array}{c}\text { Link/place of } \\
\text { publication }\end{array}$ \\
\hline & & & & $\begin{array}{l}\text { summer-open- } \\
\text { university-and- } \\
\text { student-camp / }\end{array}$ \\
\hline $8 / 1 / 19$ & $\begin{array}{l}\text { Hungarian Prime } \\
\text { Minister Viktor } \\
\text { Orban (quoted) }\end{array}$ & $\begin{array}{l}\text { Zalan, Eszter. 2019. "Orban praises von der } \\
\text { Leyen after first face-to-face." EUObserver, } \\
\text { August } 1 .\end{array}$ & 17 & $\frac{\underline{\text { https://euobserver.co }}}{\underline{\mathrm{m} / \text { political/145579 }}}$ \\
\hline $8 / 13 / 19$ & $\begin{array}{l}\text { Hungarian Prime } \\
\text { Minister } \\
\text { Spokesman } \\
\text { Zoltan Kovacs } \\
\text { (quoted) }\end{array}$ & $\begin{array}{l}\text { August } 13 \text { 2019. Boffey, Daniel. } 2019 . \\
\text { "Hungary's far-right government vilifies } \\
\text { Finland over rule of law inquiry." The } \\
\text { Guardian. }\end{array}$ & 8 & $\begin{array}{l}\text { https://www.theguard } \\
\text { ian.com/world/2019/ } \\
\text { aug/13/hungary-far- } \\
\text { right-government- } \\
\text { finland-rule-law- } \\
\text { inquiry }\end{array}$ \\
\hline $9 / 16 / 19$ & $\begin{array}{l}\text { Council of the } \\
\text { European Union }\end{array}$ & $\begin{array}{l}\text { September 19, } 2019 \text { report of the hearing } \\
\text { held by the Council on } 16 \text { September } 2019 \\
\text { Re- Values of the Union - Hungary - Article } \\
7 \text { (1) TEU Reasoned Proposal. }\end{array}$ & 20 & 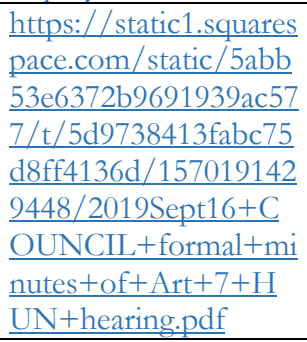 \\
\hline $9 / 2 / 18$ & $\begin{array}{l}\text { PiS Leader } \\
\text { Jarosław } \\
\text { Kaczyński }\end{array}$ & Speech before PiS Party Convention & 26 & $\begin{array}{l}\frac{\text { https://www.reuters.c }}{\text { om/article/us-poland- }} \\
\text { politics- } \\
\text { idUSKCN1LI0J2 }\end{array}$ \\
\hline $11 / 10 / 18$ & $\begin{array}{l}\text { European } \\
\text { Council } \\
\text { President } \\
\text { Donald Tusk }\end{array}$ & Speech at an anti-PiS rally in Lodz, Poland & 27 & $\begin{array}{l}\text { https://www.politico } \\
\text { eu/article/donald- } \\
\text { tusks-call-to-defeat- } \\
\text { bolsheviks-marks- } \\
\text { polish-political-return- } \\
\text { aw-and-justice-party- } \\
\text { pis-speech-in-lodz/ }\end{array}$ \\
\hline 2/19/19 & $\begin{array}{l}\text { Fidesz/Hungaria } \\
\text { n Government }\end{array}$ & $\begin{array}{l}\text { Media campaign \& social media poster } \\
\text { targeting Commission President Jean-Claude } \\
\text { Juncker }\end{array}$ & 28 & $\begin{array}{l}\text { https://www.theguard } \\
\text { ian.com/world/2019/ } \\
\text { feb/19/brussels- } \\
\text { orban-jean-claude- } \\
\text { juncker-poster-george- } \\
\text { soros-hungary }\end{array}$ \\
\hline $7 / 5 / 19$ & $\begin{array}{l}\text { EPP Leader } \\
\text { Manfred Weber }\end{array}$ & $\begin{array}{l}\text { Press coverage and Manfred Weber } \\
\text { comments following the defeat of his } \\
\text { campaign for the Commission Presidency }\end{array}$ & 29 & $\begin{array}{l}\text { https://www.politico. } \\
\text { eu/article/manfred- } \\
\text { weber-disappointed- } \\
\text { blames-emmanuel- } \\
\text { macron-and-viktor- } \\
\text { orban/ }\end{array}$ \\
\hline $12 / 1 / 14$ & UK Government & $\begin{array}{l}\text { UK Report on "Review of the Balance of } \\
\text { Competences between the United Kingdom } \\
\text { and the European Union - EU Enlargement" }\end{array}$ & 30 & $\begin{array}{l}\text { https://assets.publishi } \\
\text { ng.service.gov.uk/gov } \\
\text { ernment/uploads/syst } \\
\text { em/uploads/attachme } \\
\text { nt data/file/388422/ } \\
\text { BoC EUEnlargement } \\
\text { acc.pdf }\end{array}$ \\
\hline
\end{tabular}




\begin{tabular}{|c|c|c|c|c|}
\hline Date & Speaker & Title / description & $\begin{array}{c}\text { Trax } \\
\#\end{array}$ & $\begin{array}{c}\text { Link/place of } \\
\text { publication }\end{array}$ \\
\hline $5 / 27 / 14$ & $\begin{array}{l}\text { Council Legal } \\
\text { Service }\end{array}$ & $\begin{array}{l}\text { Opinion of the Council Legal Service Re- } \\
\text { Commission's Communication on a New EU } \\
\text { Framework to Strengthen the Rule of Law }\end{array}$ & 31 & $\begin{array}{l}\text { https://data.consilium } \\
. \text { europa.eu/doc/docu } \\
\text { ment/ST-10296-2014- } \\
\text { INIT/en/pdf }\end{array}$ \\
\hline $12 / 16 / 14$ & $\begin{array}{l}\text { Council of the } \\
\text { European Union }\end{array}$ & $\begin{array}{l}\text { Council of the European Union Press Release } \\
\text { - 3362nd Council Meeting (announcing the } \\
\text { creation of the Rule of Law Dialogue) }\end{array}$ & 32 & $\begin{array}{l}\underline{\text { https://www.consiliu }} \\
\text { m.europa.eu/media/2 } \\
\text { 4763/146348.pdf }\end{array}$ \\
\hline $1 / 12 / 12$ & $\begin{array}{l}\text { Hungarian Prime } \\
\text { Minister Viktor } \\
\text { Orban }\end{array}$ & $\begin{array}{l}\text { Speeches before the European Parliament, } \\
\text { addressing the Parliament and Commission } \\
\text { President Barroso, in a Debate concerning } \\
\text { Recent Political Developments in Hungary }\end{array}$ & 33 & $\begin{array}{l}\text { https://www.europarl } \\
\text {.europa.eu/doceo/doc } \\
\text { ument/CRE-7-2012- } \\
\text { 01-18-ITM- } \\
\text { 021 EN.html?redirect } \\
\end{array}$ \\
\hline $7 / 2 / 13$ & $\begin{array}{l}\text { Hungarian Prime } \\
\text { Minister Viktor } \\
\text { Orban (quoted) }\end{array}$ & $\begin{array}{l}\text { Speeches before the European Parliament, } \\
\text { addressing the Parliament and Commission } \\
\text { President Barroso, in a Debate concerning } \\
\text { the Tavares Report on democracy and the } \\
\text { rule of law in Hungary }\end{array}$ & 34 & $\begin{array}{l}\text { https://www.euractiv. } \\
\text { com/section/central- } \\
\text { europe/video/viktor- } \\
\text { orban-angry-at-eu-s- } \\
\text { criticism-of-hungary- } \\
\text { s-democratic-values/ }\end{array}$ \\
\hline $1 / 7 / 19$ & $\begin{array}{l}\text { The New Yorker } \\
\text { \& Kim Lane } \\
\text { Scheppele } \\
\text { (quoted) }\end{array}$ & $\begin{array}{l}\text { Descriptions by the New Yorker and by Prof. } \\
\text { Kim Lane Scheppele of Viktor Orban's } \\
\text { "dance of the peacock" and discussion of } \\
\text { how Orban self-consciously describes his } \\
\text { stalling tactics in these terms }\end{array}$ & 36 & $\begin{array}{l}\text { https://www.newyork } \\
\text { er.com/magazine/201 } \\
9 / 01 / 14 / \text { viktor- } \\
\text { orbans-far-right- } \\
\text { vision-for-europe }\end{array}$ \\
\hline
\end{tabular}

Note: Transparency appendix (Trax) entries begin on next page. Following Moravcsik (2014), for each entry we include an extended excerpt of the text/discursive interaction treated as evidence, an annotation which specifies our interpretation of the evidence and explains its relevance for our analysis, and a citation/source link that can be used to access the empirical evidence in full. See: Moravcsik, A. (2014). Transparency. PS: Political Science and Politics 47 (1), 48-53. 


\section{Appendix 1}

In December 2015, the European Commission initiated a dialogue with the Polish government under the 2014 Rule of Law Framework after national legislation gave the PiS-controlled Parliament, President, and Department of Justice full power to dismiss judges at the Polish Constitutional Tribunal. Poland's Minister of Justice, Zbigniew Ziobro criticized the decision to Commission Vice President Frans Timmermans, arguing that the decision was not undergirded on facts and constituted an attempt to infringe upon Polish democracy:

"Honorable President,

I was astonished to read your letter kindly addressed to me with respect to the Constitutional Court in Poland. The contents of the letter indicate a lack of knowledge about the factual developments related to the Constitutional Court. You had a possibility to receive from me competent information regarding this issue, e.g. by using routine working contacts between the Ministry and the European Commission. I deplore the fact that you decided not to do so. Thus, I first found out about your unjustified accusations and unfair conclusions from the media and later from the official correspondence. Those are the reasons, why I regarded your letter as an attempt to exert pressure upon the democratically elected Parliament and Government of the sovereign Republic of Poland...

...Law and Justice (PiS), which is the first political party in Polish history to win a majority in the parliamentary elections and therefore enjoys an undisputed democratic mandate, took remedial actions to reinstate pluralism in the Constitutional Court...

...Honorable President,

Today, the Polish Government is engaged in efforts to reinstate legal order and to ensure proper functioning of the Constitutional Court and, in particular, the Court's pluralism. This approach reflects the Government's profound commitment to the principles of democratic rule of law. I trust that, owing to the information that I now pass on to you, we stand together as allies in an effort to achieve these objectives.

Poland is a sovereign and democratic state. Therefore, may I ask you to exercise more restraint in instructing and cautioning the Parliament and the Government of a sovereign and democratic state in the future, despite ideological differences that may exist between us, with you being of a left-wing persuasion.

It would be my great pleasure to host you in Poland and answer any other questions that you may have.

Yours faithfully,

Zibigniew Ziobro"

Source: Letter from Polish Ministry of Justice to EU Commission VP Timmermans, January 11, 2016. Available at:

https://static1.squarespace.com/static/5abb53e6372b9691939ac577/t/5c78e3437817f7e6d9954860 $/ 1551426388869 / 2016 J a n 11+$ Poland +Letter+to+Timmermans $+4 p+$ copy.pdf 


\section{Appendix 2}

When the Commission invoked the Article 7(1) procedure against Poland in December 2017, the Polish government resuscitated its claim that foreign meddling was not grounded in fact, politically motivated, destined for a democratic backlash, and destructive to EU principles like sincere cooperation and mutual trust. Addressing member state governments in the European Council, the PiS government argued that:

"In 2015 the Polish competent authorities (President of the Republic, Parliament, and Government) initiated actions aimed at increasing efficiency of the judiciary and restoring public trust in its functioning. An independent and effective judiciary system is a crucial and indispensable element of every democratic state. The organization of judicial proceedings should create appropriate conditions for resolving legal disputes brought before the courts. At the same time, the system of nominating judges and regulating their professional responsibility should be a cornerstone of the entire judicial branch that ensures its proper functioning, safeguards its independence and preserves it from any undue, external influence.

All actions undertaken by the Polish authorities in the process of the reform were driven by the abovementioned principles. We bear in mind that due to the complexity of the discussed issues, our EU partners may still raise questions with regard to some of the introduced changes. This is why we reiterate our full readiness for dialogue and to provide further clarifications. Nevertheless, it is hard for us to accept allegations that the reform creates a risk of a serious breach of the rule of law as they have not been borne out in reality. We decided to amend some parts of the reform or return to previous solutions in order to address concerns of our EU counterparts and provide time for additional reflection. We reckon that our concrete actions and positive attitude towards the dialogue have not been met with a symmetric reaction from some of our partners...

...Taking into account the aforementioned facts we strongly believe that the procedure based on article 7 of the Treaty of the European Union no longer contributes to achieving proper understanding of the content of the reform. Quite the contrary - it started to serve as a tool of exerting political pressure instead of aiming at achieving a constructive and tangible solution.

We are aware that some of ourpartners may wish to receive additional explanations with regard to the problems presented herein. Once more we reiterate our full readiness to answer all your questions. We prefer having a detailed discussion on the substance of the reform instead of addressing general, political statements..." [pgs. 1,9.]

Source: "Summary of actions undertaken by Poland in order to address European Commission's recommendations concerning the reform of the Polish judiciary." Internal message from the Polish Government to the European Council, January 28, 2019. Available at: https://oko.press/rzad-dorady-europejskiej-komisji-i-panstw-ue-arogancka-samoobrona-ujawniamy-dokument/

\section{Appendix 3}

Immediately prior to the European Parliament's vote on triggering Article 7(1) against Hungary in September 2018, Prime Minister Viktor Orbán delivered a speech in the European Parliament that would lay the groundwork for subsequent interactions with the Council, wherein the Article 7 process has since stalled. Weaponizing the perversity thesis, Orbán claimed to defend Hungarian democracy from politically motivated encroachments, and to be upholding the EU's true spirit of constitutional diversity and international cooperation: 
"Honourable Members,

I stand here now and defend my homeland, because to Hungarians freedom, democracy, independence and Europe are matters of honour. This is why I say that the report before you is an affront to the honour of Hungary and the Hungarian people. Hungary's decisions are made by the voters in parliamentary elections. What you are claiming is no less than saying that the Hungarian people are not sufficiently capable of being trusted to judge what is in their own interests. You think that you know the needs of the Hungarian people better than the Hungarian people themselves. Therefore I must say to you that this report does not show respect for the Hungarian people. This report applies double standards, it is an abuse of power, it oversteps the limits on spheres of competence, and the method of its adoption is a treaty violation.

Honourable Members,

To us in Hungary, democracy and freedom are not political questions, but moral questions. You now seek to pass moral judgement and stigmatise a country and a people on the basis of a numerical majority. You are assuming a grave responsibility when - for the first time in the history of the European Union - you seek to exclude a people from decision-making in Europe. You would strip Hungary of its right to represent its own interests within the European family that it is a member of. We have - and will continue to have - disputes: we think differently about Europe's Christian character, and the role of nations and national cultures; we interpret the essence and mission of the family in different ways; and we have diametrically opposed views on migration. If we truly want unity in diversity, then our differences cannot be cause for the stigmatisation of any country, or for excluding it from the opportunity of engaging in joint decision-making. We would never sink so low as to silence those with whom we disagree.

Honourable President,

You also want to exclude a country that made clear decisions in previous elections to the European Parliament: in 2009 a 56 per cent majority voted for us, and in 2014 that majority was 52 percent.

Honourable Members, Ladies and Gentlemen,

We are the most successful party in the European Parliament. Our socialist and liberal opponents are understandably unhappy with our success, but to take revenge on the Hungarians for not voting for them is unfair and un-European. Furthermore, this report was written by people who are not even aware of basic facts. The report admits that it failed to send a delegation to Hungary, meaning you will be voting without there having been an adequate examination of the facts. The report includes thirty-seven major factual errors; in relation to these, yesterday every $M E P$ received a 108-page document.

\section{Honourable Members,}

Our union is held together by the fact that disputes are resolved within a regulated framework. On behalf of Hungary I, too, have made compromises and concluded agreements with the Commission on the Media Act, on the justice system, and even on certain passages in the Constitution. This report disregards agreements that were concluded years ago. But if you are free to do this and can disregard agreements at will, then what is the point of coming to an agreement with any European institution in the first place? What you are doing strikes a blow against both the European Union and the principle of constructive dialogue." 
Source: Address by Prime Minister Viktor Orbán in the debate on the so-called "Sargentini Report." September 11, 2018. Available at: https://www.kormany.hu/en/the-prime-minister/the-primeminister-s-speeches/address-by-prime-minister-viktor-orban-in-the-debate-on-the-so-called-

sargentini-report

\section{Appendix 4}

After Prime Minister Viktor Orbán's speech in the European Parliament in September 2018, the Parliament voted by 488 votes to 197 to trigger Article 7(1) and refer the matter to the Council, where the procedure has since stalled. The Hungarian delegation to the European Council consequently drafted a memo reiterating the illegality of the Parliament vote. The memo pledged allegiance to the European project while delegitimizing the Parliament's action on the basis of it being premised on outdated facts, asking the Council to commit an ultra vires act, and running roughshod over the constitutional diversity and member state equality protected by EU law:

"As regards the procedural aspects of the Resolution of the European Parliament, the Hungarian Government's position is that the method of calculating the votes on the Resolution constitutes a manifest breach of the essential procedural rules and it is deemed to be legally non-existent and void. Therefore, the Hungarian Government has brought a legal procedure to the Court of Justice of the European Union seeking for the annulment of the Resolution. Thus, the validity of the Resolution is to be decided by the Court of Justice of the European Union. In its action Hungary pleads that the European Parliament has breached Article 354 (4) TFEU, as well as Article 178 (3) of its own Rules of Procedure by excluding abstentions when calculating the votes cast. If abstentions had been counted as votes cast, the Resolution would not have been adopted.

Irrespective of the validity of the Resolution, it contains severe and serious allegations against Hungary which the Hungarian Government rejects. The procedure and the decision of the European Parliament were politically motivated. Instead of perceptions, emotions and subjective assessments, the Council should base its decision on facts, precise legal provisions and objective analysis. This puts an enormous responsibility on the Council to reestablish confidence, fact based approach, exclude double standards, provide equality of Member States and give an appropriate application of the Treaty rules. It should also be carefully considered that by making unfounded allegations against a Member State/Member States or by referring to the breach of the values of the Union merely due to political / ideological motivation, the unity of the European Union is severely undermined and the confidence among Member States or between Member States and the European institutions is seriously damaged.

As regards the findings of the Resolution, the Hungarian Government is of the view that they are unjustified. They lack and deny basic facts, they are misleading and give false interpretation of the situation in Hungary. As a result, the Resolution draws unfounded conclusions by declaring that there is a clear risk of a serious breach by Hungary of the values of the Union.

The motivation of the European Parliament was deeply political and should be considered in the context of party politics and ideological divisions between different European political forces as to the future of Europe and diverging answers to the migration challenges less than one year before the May 2019 European Parliamentary elections. The procedure in the Council, under Article 7(1) TEU, has a clear legal nature and should follow the facts, rules and the principles of the Treaties... 
... We believe that it is important for all of you to know that the European Parliament adopted its Resolution on Hungary offering limited possibility to the Hungarian Government to provide full information and to make clear its position on the issues raised during the preparatory process...

...In fact, the European Parliament scrutinised the developments only from 2010 onwards. One cannot disregard the political motivation behind this. In the reasoned proposal the European Parliament lists all kinds of critical voices over the last eight years against Hungary regardless of the fact that most of them have become obsolete as these cases have been solved or closed in the meantime. In addition, the European Parliament does not provide any justification or explanation on how the different questions raised represent a clear risk of a serious breach by Hungary of the values of the Union. It is more like a compilation of concerns, allegations and perceptions by other European or international fora edited by the European Parliament - bowever it is not a reasoned proposal at all. Article 7 TEU is a serious procedure, therefore it should not be used in an arbitrary way but strictly in compliance with the Treaties...

...The present procedure is applied to Hungary. However, as this is the first such case upon the Resolution of the European Parliament, the modalities and the approach to be applied now set a precedent for the future. In this context, it is crucial and lies in the interest of the Union as a whole to clearly declare that any procedure related to the rule of law must be strictly based on the principles of the rule of law...

... Since 2010, in-depth structural reforms have been introduced in Hungary often having an effect on political and economic interests both domestically and abroad. These legislative changes have always been in the focus of attention in general and also of the European institutions, in particular that of the European Commission. No Member State has ever been subject to such a thorough scrutiny by the European Commission as Hungary was during the last eight years... Rule of law is the basis of our democracies, our societies, therefore, we must use with great caution any allegation undermining its respect by any of our Member States... Equality of Member States also means that the same regulation should be assessed against the same criteria.

Besides the equality of Member States, other basic principles provided for by the Treaties shall also be strictly respected as enshrined in the well-established case law of the Court of Justice of the European Union. According to Article 4(2) TEU, the Union must respect essential State functions, which undoubtedly include what might be defined as the State's internal self-organisation. Furthermore, the principle of conferral of powers laid down in Article 5(1) and (2) TEU has not conferred on the Union the power to intervene in the internal organisation of its Member States.

We all belong to the same Union, but we have different constitutional traditions. Therefore, simply having different rules as regards our constitutional order, does not justify questioning each other's position on the basis of the values of the European Union. On the contrary, the Treaty itself calls for the respect of the Member States' constitutional traditions...

... Under such circumstances, it is important to follow the principles agreed with consensus by the Council in its conclusions from December 2014. Non-discrimination; equality of Member States; evidence-based and nonpartisan approach must serve as guiding principles in this and all other similar procedures. Double standards must be excluded in order to avoid undermining public confidence in our common institutions. All concerns may be raised, but opportunity should be given to clarify allegations, including the possibility to convince the Members of the Council in a fair and transparent procedure...

...Finally, the general public in Hungary and in other Member States closely follows the process. It is essential to maintain public support, as well as confidence in public institutions and in Member States' relations. 
Therefore, it is the responsibility of the Council to demonstrate that the Article 7 procedure is objective, transparent, that it provides the equality of the Member States, still focusing on unity and on mutual respect while being in line with the Treaties.

Hungary deems its accession to the European Union as a historical success. Therefore it is appalling that existing and legitimate political debates are framed as rule of law issues..." [pgs.1-3, 5-6.]

Source: "Information on the Resolution on the situation in Hungary adopted by the European Parliament on 12 September 2018." November 13, 2018 memo by the Hungarian delegation to the European Council Available at:

https://static1.squarespace.com/static/5abb53e6372b9691939ac577/t/5c564791ee6eb0443f6f47e4 $\angle 1549158302887 / \mathrm{HUN}+2018+\mathrm{Nov}+$ misinformation + note + submitted + to + and + shared + by $+\mathrm{Cou}$ ncil+INITIALLY+CONFIDENTIAL+but+successful+FoI.pdf

\section{Appendix 5}

In 2019, Finland assumed the rotating Council presidency and promised to place the rule of law to the top of the agenda for the European Semester. Hungary released a statement arguing that the agenda modification was politically motivated and a breach of competence:

"The statements on the Hungarian judicial system are politically motivated, biased and do not reflect the reality as the relevant legislative environment has not changed in the reporting period. In addition, the text fails to establish the direct relevance of the highlighted issues for the objectives of the European semester, thus undermining the credibility of the process.

Consequently the recommendations related to judicial independence and access to information are unjustified, unsubstantiated and therefore unacceptable. They cannot serve as the basis of a meaningful economic policy dialogue and are not conducive to genuine political ownership.

Such recommendations do not serve the purposes of the semester process and must be avoided in the future.

The modifications proposed by the Finnish Presidency fail to remedy the fundamental shortcomings of the Recommendations. The text still contains a value judgement that is not substantiated by facts and goes well beyond the material scope of the European Semester.

As a result, the Presidency, at its own discretion, submits a text to the Council which does not allow Hungary to support the adoption of its own recommendations given that is not in line with the content and legal constraints of the Semester."

Source: July 11, 2019 Declaration of the Hungarian Government on the June 6, 2019 Council Recommendation on the 2019 National Reform Programme of Hungary and delivering a Council opinion on the 2019 Convergence Programme of Hungary. Available at: https://twitter.com/ProfPech/status/1149226846162210817

\section{Appendix 6}

In November 2017, the Polish delegation in the European Council argued that the Commission's claim that the PiS government was undermining judicial independence contradicted the European 
Court of Justice's (ECJ) case law and threatened to undermine international cooperation, mutual trust, and the European Arrest Warrant system. At the same time, the Polish delegation emphasized the importance of good-faith dialogue, respecting the constitutional diversity of member states, and the importance of waiting for the full factual record of any reform to be evident before considering to take any action:

..."The Polish delegation expressed gratitude for the first hearing on 26 June 2018, and stressed that it had been a very good opportunity to exchange views and hold a fact-based, substantial and fair debate. It stated that the Council was a place for a neutral, fact-based debate about reform of the justice system in a Member State and that the hearing should be limited to facts, giving the opportunity to present any missing aspects of the analysis of the situation in Poland. Poland was aware of the concerns raised by the EU institutions, some Member States and other international bodies. However, it was necessary to underline that, according to Article 67 TFEU, regulation of the judicial system was a competence of the individual Member State, and the EU respected the different legal systems and constitutional traditions of the Member States. That did not exclude a debate such as this on whether the implementation of such regulation was in accordance with the rule of law. Recent reforms of the judiciary, and in particular of the law on the Supreme Court (SC) and the National Council of the Judiciary (NCJ), had only been implemented in the last few months and more time and experience were needed to assess their performance"...

..."The French delegation reiterated the question asked by the German and Danish delegations on Poland's follow-up to the possible CJEU judgment concerning the retirement of judges. Following the Dutch question, Poland was asked how the disciplinary proceedings might affect the independence of judges, in particular in the light of the CJEU ruling of 25 July stating that disciplinary proceedings had to guarantee that no political control would be imposed on judicial decisions.

The Polish delegation repeated that there were no disciplinary procedures against any of the judges who had filed prejudicial questions. The CJEU judgment of 25 July was a careful judgment, confirming that general doubts about a justice system did not justify non-implementation of European Arrest $W$ arrants ( $\mathrm{E} A W$ s). Otherwise, it might put an end to the $\mathrm{E} A W$ since a lack of proper protection in the Member State's judicial system concerned at least 30 other cases too"... [pgs. 2, 7].

Source: " Rule of Law in Poland / Article 7(1) TEU Reasoned Proposal." November 5, 2018 Report of the hearing held by the Council on 18 September 2018. Available at: https://static1.squarespace.com/static/5abb53e6372b9691939ac577/t/5c564874a4222f53ddeb2a08 $\angle 1549158524254 / 2018$ Sept+Council+2nd+HEARING+report+released+via+FoI.pdf

\section{Appendix 7}

As Finland assumed the rotating Presidency of the European Council, Prime Minister Viktor Orbán delivered a much-publicized speech in July 2019 charging Finland with hypocrisy and with jeopardizing equality and mutual trust in the EU by embracing double-standards in rule of law enforcement that it would fail to meet:

" ...Well, Ladies and Gentlemen,

Today Hungary is on a promising course: sound finances, falling debt, strong growth, rising wages, strengthening small and medium-sized enterprises, growing families and vigorous nation-building. Of course everyone can and 
should perform better. Individual Hungarian citizens, Hungarian businesses and the Hungarian government can and should do their jobs better; but the reality is that today the threat to Hungary's continued progress on its promising course does not come from inside the country, but from outside. What is happening in Hungary today - and what will be happening in the year abead of us leading up to our next meeting - is our countering of these attacks and our attempts to defend Hungary against them.

What are they? We've already successfully countered the first attack. This would have shown itself in the selection of unsuitable and hostile people to lead the European institutions that are important to us. I will not elaborate on every detail, but this was prevented through a number of complicated manoeuvres. Everywhere we have blocked George Soros's candidates. Everywhere. We've prevented ideological guerrillas from being installed at the head of important European institutions, and to lead the Commission we've succeeded in choosing a mother of seven who has a practical approach. Of course this doesn't end the struggle within the institutions; that will end in October, when the entire landscape is revealed. Two things can be said with certainty. The first is that the Commission, which has launched so many attacks on Hungary, has even now in recent days - as it is on its way out - launched another attack. It is taking a number of Hungarian laws to the European Court. So this Commission must return to its role as laid down in the Founding Treaty of the European Union: to act as the guardian of the treaties. And it must abandon its political activism. It is not a political body: it is not its remit to have a programme, and it is not its remit to launch political attacks on Member States. That is what happened in the earlier appointed "Juncker Cabinet", and it must be stopped. This has always been at odds with the European Union's founding treaties and principles. Now there is a chance for this...

...Well, the second such threat we need to deal with is the threat from the international arena. The fact is that there have been serious mistakes in the European Union over the last five years...

... Of course, as Justice Minister Judit Varga is here, let's not forget that we will be facing our battles here on the rule of law. Here we need strong nerves: not in representing our position, as the Minister has already shown is possible, but in preventing ourselves from bursting out laughing and thus offending our partners. That is the hardest part; that requires strong nerves and self-control. Now, for example, we're entering a period in which our Finnish friends will be evaluating the situation of the rule of law in Hungary. We'll be doing this with our Finnish friends. And Finland is a country, Ladies and Gentlemen, where there is no constitutional court. The defence of the Constitution is delegated to a special parliamentary committee set up for that purpose. Imagine the condition of the rule of law in Hungary if we simply announced the dissolution of the Constitutional Court and said that Parliament's Committee for Constitutional Affairs would be responsible for constitutional review! This is more or less the situation in Finland. Or to give you another nice example: in Finland, the Academy of Sciences is under the supervision and control of the Ministry of Education. Imagine if we'd brought the debate on the Hungarian Academy of Sciences to an end by simply giving the right to oversee and direct the Academy to the Minister of Education. This isn't the case, Minister Kásler, but just imagine if it was! Or just consider the state of the rule of law in Finland, where judges are appointed by the President of the Republic, on the recommendation of the Minister of Justice. The President of the Republic, on the recommendation of the Minister of Justice! Therefore we need a nervous system, a strong nervous system, to enable us to show due respect, and answer questions politely - not with a smile or a laugh - when our Finnish friends ask us about and delve into the rule of law in Hungary..."

Source: Prime Minister Viktor Orbán's speech at the 30th Bálványos Summer Open University and Student Camp. July 27, 2019, available at: http://abouthungary.hu/speeches-and-remarks/primeminister-viktor-orbans-speech-at-the-30th-balvanyos-summer-open-university-and-student-camp/ 


\section{Appendix 8}

Following Prime Minister Viktor Orbán's July 27, 2019 speech at Bálványos Summer Open University and Student Camp, his spokesperson reiterated Orbán's critique of Finland jeopardizing equality and mutual trust in the EU by hypocritically embracing double-standards against Hungary, as reported by The Guardian:

"Finland has pledged to pursue a bearing into alleged breaches of the rule of law by Hungary's far-right government after a campaign of vilification led by the prime minister, Viktor Orbán.

Orbán and his spokesman, Zoltán Kovács, have launched a series of attacks in recent weeks ranging from criticism of the level of domestic violence in Finland to the purchase of strategically important Finnish islands by Russian oligarchs.

As the member state holding the EU's rolling presidency until the new year, the Finnish government is responsible for chairing meetings of the member states and pushing forward the bloc's agenda.

The European parliament took the unprecedented step last September of asking member states to determine whether Hungary had breached the bloc's founding values in its overhaul of the country's judiciary and alleged failure to respect freedom of expression, religion and equal treatment under the law.

In the most recent broadside, Kovacs, who is Hungary's secretary of state for international communication and relations, wrote that Finland "doesn't have a constitutional court, independent judiciary or press freedom, it also shows signs of other serious problems as well".

He raised the "petrifying" numbers of women undergoing female genital mutilation and the "grave threat" facing "freshly settled religious minorities"..."

Source: Boffey, Daniel. 2019. "Hungary's far-right government vilifies Finland over rule of law inquiry." The Guardian, August 13.

\section{Appendix 9}

In his 2012 State of the Union Address, European Commission President José Manuel Barroso invoked the futility thesis by claiming that the EU lacked the appropriate tools to effectively intervene in Hungary and Poland to defend constitutional democracy:

"...A political union also means that we must strengthen the foundations on which our Union is built: the respect for our fundamental values, for the rule of law and democracy.

In recent months we have seen threats to the legal and democratic fabric in some of our European states. The European Parliament and the Commission were the first to raise the alarm and played the decisive role in seeing these worrying developments brought into check.

But these situations also revealed limits of our institutional arrangements. We need a better developed set of instruments - not just the alternative between the "soft power" of political persuasion and the "nuclear option" of article 7 of the Treaty. 
Our commitment to upholding the rule of law is also behind our intention to establish a European Public Prosecutor's Office, as foreseen by the Treaties. We will come with a proposal soon..."

Source: September 12, 2012 State of the Union speech by European Commission President José Manuel Barroso. Available at: https://europa.eu/rapid/press-release SPEECH-12-596 en.htm

\section{Appendix 10}

Following the 2012 State of the Union Address by European Commission President José Manuel Barroso, the Commission legal service drafted a communication reiterating that it lacked the appropriate tools to effectively protect the rule of law in Hungary and Poland:

"... recent events in some Member States have demonstrated that a lack of respect for the rule of law and, as a consequence, also for the fundamental values which the rule of law aims to protect, can become a matter of serious concern. During these events, there has been a clear request from the public at large for the EU, and notably for the Commission, to take action. Results have been achieved. However, the Commission and the EU had to find ad hoc solutions since current EU mechanisms and procedures have not always been appropriate in ensuring an effective and timely response to threats to the rule of law.

The Commission is the guardian of the Treaties and has the responsibility of ensuring the respect of the values on which the EU is founded and of protecting the general interest of the Union. It must therefore play an active role in this respect. In September 2012, in his annual State of the Union speech to the European Parliament, President Barroso said: "We need a better developed set of instruments, not just the alternative between the 'soft power' of political persuasion and the 'nuclear option' of Article 7 TEU. In the following year's speech, he said that "experience has confirmed the usefulness of the Commission role as an independent and objective referee. We should consolidate this experience through a more general framework [...]. The Commission will come forward with a communication on this. I believe it is a debate that is key to our idea of Europe..." [pg. 2].

Source: March 11, 2014 Communication from the Commission to the European Parliament and the Council on a New EU Framework to Strengthen the Rule of Law. Available at: https://eurlex.europa.eu/legal-content/EN/TXT/PDF/?uri=CELEX:52014DC0158\&from=EN

\section{Appendix 11}

As late as July 2017 (five months before triggering Article 7(1) against Poland), Commission VicePresident Frans Timmermans remained reluctant to activate Article 7(1) and hoped to pursue a softer, dialogue-based approach to the extent that it proved constructive:

"As you know, the Commission already concluded in our 2016 Recommendations that there is a systemic threat to the rule of law in Poland...

... On 13 July 2017, I wrote to both the Polish Minister of Foreign Affairs and the Polish Minister of Justice with my concerns about the new proposals.

I have asked the two Ministers to relaunch a dialogue and I have invited them to Brussels.

The letter explicitly underlined the importance of not adopting the new proposals.

Unfortunately, on 15 July 2017 two of the laws were approved by the Parliament. 
The rule of law is one of the values on which our Union is founded and which defines our Union.

This is no matter only for the Polish people. What is happening in Poland affects the Union as a whole. All of us, every single Member State, every citizen of the Union.

The new laws are not all yet officially in place. So today we cannot take formal decisions just yet.

But we can send a clear and strong political message.

First of all, we will swiftly prepare a third recommendation under the Rule of Law Framework to be formally adopted by College next week;

Secondly, we will swiftly prepare infringement procedures for breach of $\mathrm{EU}$ law, also to be launched next week;

Finally, with regard to Article 7, the option of triggering Article 7 of the Treaty was part of the discussion and it should come as no surprise to anyone that, given the latest developments, we are coming very close to triggering Article 7.

Having said all of this, our hand is still extended to the Polish authorities for dialogue. But dialogue must be aimed at redressing the situation. And dialogue, if it happens or not, will not stop the Commission from taking any measures it deems necessary in this framework."

Source: 19 July 2017 Opening remarks of First Vice-President Frans Timmermans, "College readout on grave concerns about the clear risks for independence of the judiciary in Poland." Available at: http://europa.eu/rapid/press-release SPEECH-17-2084 en.pdf

\section{Appendix 12}

On October 25, 2018, the Commission began seriously considering the possibility of withholding EU funds to both recalcitrant member states, and proposed a conditionality regulation to that effect. Yet in a resuscitation of the perversity, jeopardy, and futility theses, the legal service of the European Council quickly circulated a (then) non-public opinion channeling the view of unspecified member state delegations that rule of law conditionality would be ultra vires: It would jeopardize the Article 7 procedure by establishing a parallel means to sanction states for rule of law deficiencies, the Commission action was futile because it lacked the legal authority to adopt a rule of law conditionality mechanism vis-à-vis the member states, and if implemented, the Commission's proposal would violate EU by, among other things, not identifying which rule of law violations would be necessary and sufficient for the mismanagement of EU funds:

"During the meeting of the Ad Hoc Working Party on the Multiannual Financial Framework. (MFF) of 4 September 2018, delegations raised various issues of compatibility with the Treaties of the Commission proposal for the establishment of a mechanism on the protection of the Union's budget in case of generalised deficiencies as regards the rule of law in the Member States ("the proposal"). In particular delegates raised issues concerning the compatibility of the proposed mechanism with Article 7 of the TEU, the choice of Article 322(1)(a) TFEU as an appropriate legal basis and the legality of the procedure for the adoption of measures under the mechanism. This opinion responds to that request... 
As a matter of fact, the reference to the generalised deficiencies in the rule of law as the premise to activate the mechanism is neither necessary nor sufficient to establish a link with the sound implementation of the budget...

In this sense, neither Article 3 nor Article 5 of the proposal define the standard of proof incumbent on the Commission (as the institution in charge of proposing the measures in case of a general deficiency as regards the rule of law) where the latter is held to provide serious and reasonable elements to justify that the financial interests of the Union are at risk or are actually being affected...

Finally, under Article 4(3) of the proposal the measures "shall be proportionate to the nature, gravity and scope of the generalised deficiency as regards the rule of law" but not to the gravity of the actual or potential consequences for the EU budget. This confirms the conclusion that the proposed mechanism does not establish a genuine link between the measures to be adopted and the protection of the budget but rather aims at sanctioning the violation of the rule of law as such, as is the case under the procedure laid down by Article 7(3) TEU.

In the light of the above, the conditionality regime envisaged in the proposal cannot be regarded as independent or autonomous from the procedure laid down in Article 7 TEU, as its respective aims and consequences are not properly distinguished and risk overlapping with each other. Therefore, as it currently stands, the proposal would in reality establish a parallel mechanism of verification and control of compliance with a fundamental value of the Union, the rule of law, for which Article 7 TEU provides the relevant procedure...

A specific link between an identified deficiency and the inability to satisfy the objectives of a given measure is at the core of any conditionality attached to EU funding...

However such cases of fundamental malfunctioning would have to be identified with sufficient precision (see above point 21), rather than drawn from an open ended list as in current Article 3(1)...

The Council Legal Service is of the opinion that

- the reference to the rule of law in Article 3 of the proposal as a condition for triggering the proposed mechanism is neither necessary nor sufficient to establish a link with the sound implementation of the EU budget, which is required for a genuine spending conditionality;

- a genuine conditionality mechanism cannot be based on the presumption that a risk for the EU budget necessarily exists once certain deficiencies are qualified as generalised. Rather, it requires that the existence of such a risk is established on the basis of a explicit standards and criteria;

- the conditionality regime envisaged in the proposal as it currently stands, cannot be regarded as independent or autonomous from the procedure laid down in Article 7 TEU, as the respective aims and consequences of both procedures are not properly distinguished and risk overlapping with each other...

Source: October 25, 2018 Opinion of the Legal Service of the European Council, Re-Proposal for a Regulation of the European Parliament and of the Council on the protection of the Union's budget in case of generalized deficiencies as regards the rule of law in the Member States, Available at: https://drive.google.com/file/d/1Bl1roGM0KLEUU7koVUudRglZh-EMIvL7/view

\section{Appendix 13}


In 2013, former Hungarian Prime Minister and center-left opposition leader Gordon Bajnai invoked the perversity thesis and warned the EU not to intervene too strongly in Hungary. His remarks were reported by the Financial Times:

"...Hungary's parliament motion, put forward by members of Mr Orban's Fidesz, said the Tavares report "arbitrarily defines requirements, arbitrarily introduces new procedures and creates new institutions which stand in violation of Hungary's sovereignty guaranteed in the EU Treaty".

Mr Orban bimself used the analogy of the Soviet Union, telling a radio interview: "Since the rule of the Soviet empire, no other external power has dared to try to curb the sovereignty of Hungarians openly."

The Fidesz government has alleged the report resulted both from a socialist-led conspiracy against it and pressure from powerful west European utility companies on their governments after Mr Orban forced them to cut energy prices in Hungary.

But Gordon Bajnai, former prime minister of a left-of-centre technocrat government in 2009-10 and now an opposition leader, said Mr Orban's clash with Brussels was "not about protecting Hungary but about protecting his oversized power - the power to build an eastward-looking crony capitalism and a managed democracy".

"Such a system cannot be consolidated within the framework of the European Union," he said. "However, this power can only be brought down by the Hungarian voters and not by any external influence."'"

Source: Buckley, Neil, Fontanella-Khan, James, and Kester Eddy. 2013. " EU weighs fines for democratic breaches after Hungary tensions." Financial Times, July 11, 2013. Available at: https://www.ft.com/content/3901b64c-ea12-11e2-913c-00144feabdc0

\section{Appendix 14}

In 2015 European Commission Vice-President Frans Timmermans expressed worries about a perverse effect following a robust intervention to uphold the rule of law in Hungary, citing the "Haider affair" as a historical precedent. In that 2000 controversy, EU member states suspended diplomatic relations with Austria after the far-right Freedom Party came to power in the a new government coalition. While these sanctions were imposed outside the EU Treaty framework, the ensuing popular backlash weighed heavily on Timmermans' (and member state governments') minds. In a keynote address at Tilburg University in Augus 2015, Timmermans expressed his worries as follows:

"... So what happens where fundamental values are disrespected in a Member State outside the scope of EU law? There are no infringement proceedings that apply, but there is the special mechanism in Article 7 of the EU Treaty, which can lead to the suspension of the Member State's rights, including its voting rights. Given its magnitude, the threshold for activating the mechanism (both on substance and voting requirements), are demanding. It is a measure of last resort - not to be excluded, but I would hope that we never let a situation escalate to the stage that it would require its use. I believe that the case of Austria, with Jörg Haider's party joining the government, has weakened the EU's capacity to react in such a case. It was a political response which completely backfired at the time, and since then Member States have been reluctant to take issue with other Member States on this basis. That is one of the challenges I personally will have to face in the coming years..." 
Source: Frans Timmermans. Keynote speech at Conference on the Rule of Law, Tilburg University, 31 August 2015. The link to the announcement has been deactivated on the Commission website, but the text of the speech is still available at:

https://web.archive.org/web/20171004031216/https://ec.europa.eu/commission/commissioners/ 2014-2019/timmermans/announcements/european-union-and-rule-law-keynote-speechconference-rule-law-tilburg-university-31-august-2015 en

\section{Appendix 15}

Echoing concerns about perverse effect expressed by European Commission Vice-President Frans Timmermans vis-à-vis Hungary in 2015, in 2016 Politico quoted EU officials expressing similar worries vis-à-vis Poland, suggesting that the perversity thesis was taken seriously and perceived as credible amongst EU policymakers:

"...Several diplomats said the EU's Poland problem is mainly a Commission concern at this point and isn't creating serious problems in dealings among member countries. "The Poles are not sidelined in meetings," said one Eastern European diplomat, who added that few are talking about taking the drastic step of depriving Poland — the EU's sixth largest member country — of its voting rights in the Council.

Poland's heated rhetoric in recent days has raised concern in Brussels that the situation could spin out of control if the EU doesn't react. While the EU could use other tools to put pressure on Poland, including by carrying out tighter scrutiny of EU spending in the country, finding the right approach was crucial, diplomats said.

"There is the idea that this is a case of emerging populism and that we shouldn't use any tough method which would turn the Polish population against Europe," said an EU diplomat. "We can't be counterproductive..."

Source: De la Baume, Maia. 2016. "Brussels Struggles with its Poland Problem." Politico, May 25. Available at: https://www-politico-eu.ezproxy.uio.no/article/pis-commission-human-rights-warsaweurope-struggles-to-solve-its-poland-problem/

\section{Appendix 16}

That the "Haider affair" prompted some EU leaders to consider triggering Article 7 bolstered the plausibility of Hungary and Poland's claims that all states could be threatened by the breakdown of mutual trust and the turn to nuclear options. Rui Tavares - who authored the European Parliament's 2013 "Tavares report" on the breakdown of constitutional democracy in Hungary - explained that a stubborn commitment to dialogue and sincere cooperation belied reluctance to jeopardize international cooperation, as quoted by Foreign Policy:

"...Dubbed the "nuclear option," the ultimate "weapon" against a member state, Article 7 has never been used. Nor is it likely to be in the near future. Article 7 "is unusable now, as it requires unanimity among member states. It was the product of the optimism of the beginning of the century," argues Rui Tavares, a former member of the European Parliament who worked on a report on the state of democracy in Hungary in 2013.

As this demonstrates, tools at the EU's disposal require its member governments to decide to sanction a fellow member. And that is unlikely to happen, thanks to a "gentlemen's club" agreement that Taraves sums up as "Ifyou don't talk about my case, I don't talk about your case"..." 
Source: Zalan, Eszter. 2016. "Can Europe Stand Up to Its Own Strongmen?" Foreign Policy, March 10. Available at: https:// foreignpolicy-com.ezproxy.uio.no/2016/03/10/can-europe-stand-up-to-itsown-strongmen/

\section{Appendix 17}

Upon being elected president of the European Commission in 2019, Ursula von der Leyen reiterated reluctance to take a forceful stand against Hungary in defense of the rule of law, invoking the jeopardy and perversity theses. The comments were made following a meeting with Hungarian Prime Minister Viktor Orbán in July, as quoted by EUObserver.

"..."We have made a good decision so far," Orban said told Hungary's public broadcaster after the meeting, adding that it was a good decision to keep "ideological gorillas", referring to Timmermans, away from the commission presidency, and nominate someone with a "pragmatic instinct".

Orban described von der Leyen as a politician "who has the same questions in her thoughts about the future as us", speciffing the future of children and families, security, and a common European force and the development of the military industry.

Von der Leyen tweeted after the meeting that she held a "good talk" about her political guidelines with Hungary's premier...

Von der Leyen told the European parliament before MEPs approved her nomination that "there can be no compromise when it comes to respecting the rule of law".

She later then said in an interview that in central and eastern European countries "many feel that they're not fully accepted, and if we guide debates as sharply as we have done, it contributes to countries and peoples believing that they are being targeted as a whole".

"We must all learn that full rule of law is always our goal, but nobody's perfect," she added then.

Orban confirmed on Thursday that von der Leyen is "sensitive" to issues such as migration, and also in this respect "she is able to think with central Europeans' bead"..."

Source: Zalan, Eszter. 2019. "Orban praises von der Leyen after first face-to-face." EUObserver, August 1. Available at: https://euobserver.com/political/145579

\section{Appendix 18}

In a June 26, 2018 hearing in the European Council concerning the Article 7(1) procedure against Poland, the Polish delegation reiterated that any further action would not be fact-based and premature. The delegation warned that the Council stood to set a legal precedent for the future and the responsibility for any failures in process, for acting prematurely without all the facts, or for failing to respect the diverse constitutional traditions of the member states would fall on the Council:

"... The Polish delegation stressed that since the use of Article 7(1) TEU set a precedent in the EU, procedural aspects were of great importance. The ongoing dialogue was a sensitive issue in Poland and the EU. At this 
stage, the Council was responsible for taking over the process, which set a precedent for the future. The process and its outcome were now exclusively the responsibility of the Council and the Member States...

... On the separation of powers: there was no doubt that the separation of powers was a fundamental principle of the Polish constitution. However, the balance was different in each of the Member States. There were different constitutional traditions. The concessions and amendments offered so far were neither minor nor cosmetic but fundamental and of a systemic nature. Now these amendments were entering into force and only practice over time would show if further corrections were required. Any definite assessment at this stage would be premature. It was for the Council and the Member States to take responsibility concerning the Article 7 procedure and to assess the situation..." [pgs. 2,10]

Source: August 8, 2018 Report of the hearing held by the Council on 26 June 2018 Re-Rule of Law in Poland / Article 7(1) TEU Reasoned Proposal. Available at: http://www.statewatch.org/news/2018/aug/eu-council-rule-ofLaw-poland-10906-18.pdf

\section{Appendix 19}

In a December 11, 2018 hearing in the European Council concerning the Article 7(1) procedure against Poland, the Polish delegation reiterated its commitment to dialogue and emphasized the need for EU institutions to not take any action in the absence of having received all the facts from the Polish delegation. It claimed that Polish reforms of the National Council of the Judiciary were modeled after those of other EU member states, implying that any neutral and fact-based assessment would exonerate Poland:

..."The Polish delegation referred to the Polish reply of 21 November 2018 informing the Commission about the new law enabling retired judges to return to active duty and revoking the President's power to extend the term of Supreme Court judges. The delegation voiced their belief that the Polish authorities deserve to receive the Commission's assessment on the Polish draft law within a reasonable timeframe. Taking into consideration recent events, the delegation asked the Member States how they saw the future developments of the Article 7 procedure, especially as the most pressing issue (the early retirement of judges) had been remedied by the Polish government...

... All the changes that had been implemented in April and May were the result of the fruitful dialogue with the Commission... Concerning the NCJ, it was stated that the model chosen in Poland complied with European standards and was similar to existing models in other Member States. The reform had, among other things, introduced live broadcasted hearings of candidates for the NCJ and ensured that the selected members could not be removed from their position during the course of their four-year term. The next part of the presentation concerned the Constitutional Tribunal and focused, among other things, on guarantees of its impartiality and the publication of judgments following the Commission recommendation. With regard to further steps, it was noted that the Article 7(1) TEU procedure needs to remain objective and fact-based and take into account not only the legal text but also its practical application. Poland concluded by expressing its openness to a dialogue with the Council, the Member States and the Commission"...

... The German delegation asked whether there was a time schedule for the implementation of further reforms (e.g. concerning 350 ongoing disciplinary proceedings or the situation in the NCJ). It also asked how other concerns, e.g. those raised in the Venice Commission reports, would be addressed. 
The Polish delegation replied that it would need more clarification on the facts referred to in the German delegation's question, as these did not correspond to the data available to the Polish delegation. The Polish delegation called upon other delegations not to refer to figures where the source was unknown or unofficial"... [pgs. 2-3, 6].

Source: December 20, 2018 report of the hearing held by the Council on 11 December 2017 Re- Rule of Law in Poland / Article 7(1) TEU Reasoned Proposal. Available at: https://static1.squarespace.com/static/5abb53e6372b9691939ac577/t/5c5648d9085229a138ae9015 /1549158652559/2018Dec+Council+3rd+HEARING+report+released+via+FoI.pdf

\section{Appendix 20}

In a September 2019 hearing in the European Council concerning the Article 7(1) procedure against Hungary, the Hungarian delegation reiterated its argument that the triggering of Article 7(1) by the Council was illegal and called the procedural legitimacy of the entire Article 7 process into question. Nevertheless, the Hungarian delegation reiterated its loyalty to sincere cooperation and dialogue. It reiterated also that Hungary was being subjected to unprecedented scrutiny for a broader set of practices - thereby jeopardizing the principles of mutual trust and sincere cooperation. It concluded by emphasizing the importance to taking the time to dialogue and discuss the factual matters regarding reforms in Hungary:

..."The Hungarian delegation was then given the floor. The Hungarian delegation referred to its updated information note of reply of 12 September 2019 (12133/19) and stated that it was ready to provide further information and clarification. It stated that the European Parliament's Reasoned Proposal did not contribute to the unity of the Union and that it had been adopted in such way as to breach the European Parliament's rules of procedure. The delegation expressed the view, therefore, that the procedure pursuant to Article 7(1) TEU lacked a legal basis. Nevertheless, it stated that Hungary would participate constructively in the procedure, in a spirit of cooperation... It stated that Hungary bad been subject to unprecedented international scrutiny and that the resources and reports were available to all interested parties.

The delegation stated that, although the Union's values were founded on common constitutional traditions, Hungary did not expect all Member States to follow exactly the same trajectory. This applied, for instance, in the matter of the creation of constitutional courts. In Hungary, there was overwhelming public support for EU integration, and EU membership was seen as beneficial. In the area of migration there was, however, a need to restore the balance between individual rights and the public interest...

... On the issue of media freedom, the Commission and the Council of Europe had examined the current media regulation in 2011. They had made a positive assessment at the time... Media concentration was similar or higher in other Member States...

...The Hungarian delegation stated that it had already replied on the issues of freedom of expression and the media. With regard to academia, the new law on higher education had been adopted in 2012 and an assessment was necessary after 5 years. The aim of this was to provide quality higher education. Amendments had been introduced to create a level playing field between Hungarian institutions and institutions that were based in another country. Requirements were no more stringent than in other Member States. The government had always consented to the extension of deadlines for compliance by institutions... 
...In its closing comments, the Hungarian delegation welcomed the fact that sufficient time had been given to cover in sufficient detail the various issues discussed and to present the Hungarian context. Only one conclusion was possible: there was no systemic risk of a breach of Union's values by Hungary. All further procedural steps should have the support of a clear majority of Member States"... [pgs. 2-3, 5-6, 9].

Source: September 19, 2019 report of the hearing held by the Council on 16 September 2019 ReValues of the Union - Hungary - Article 7 (1) TEU Reasoned Proposal. Available at: https://static1.squarespace.com/static/5abb53e6372b9691939ac577/t/5d9738413fabc75d8ff4136d /1570191429448/2019Sept16+COUNCIL+formal+minutes+of+Art+7+HUN+hearing.pdf

\section{Appendix 21}

On September 12, 2018, the European Parliament adopted a resolution triggering Article 7(1) of the Treaty on European Union against Hungary for violations of Article 2 values. The list of specific violations was adopted in its Annex based on a report developed in the LIBE Committee by lead rapporteur Judith Sargentini (Green MEP, the Netherlands). The resolution summarized these violations as they related to the following:

"The European Parliament,

... 1. States that the concerns of Parliament relate to the following issues:

- the functioning of the constitutional and electoral system;

- the independence of the judiciary and of other institutions and the rights of judges;

- corruption and conflicts of interest;

- privacy and data protection;

- freedom of expression;

- academic freedom;

- freedom of religion;

- freedom of association;

- the right to equal treatment;

- the rights of persons belonging to minorities, including Roma and Jews, and protection against hateful statements against such minorities;

- the fundamental rights of migrants, asylum seekers and refugees;

- economic and social rights.

2. Believes that the facts and trends mentioned in the Annex to this resolution taken together represent a systemic threat to the values of Article 2 TEU and constitute a clear risk of a serious breach thereof..."

"4. Submits, therefore, in accordance with Article 7(1) TEU, the annexed reasoned proposal to the Council, inviting the Council to determine whether there is a clear risk of a serious breach by Hungary of the values referred to in Article 2 TEU and to address appropriate recommendations to Hungary in this regard"

Source: European Parliament Resolution of 12 September 2018 on a proposal calling on the Council to determine, pursuant to Article 7(1) of the Treaty on European Union, the existence of a clear risk of a serious breach by Hungary of the values on which the Union is founded (P8_TA(2018)0340). Available at http://www.europarl.europa.eu/doceo/document/TA-8-2018-0340 EN.html.

\section{Appendix 22}


On December 20, 2017, the European Commission Vice President Timmermans announced that the Commission was referring Poland to the Council for breaching the values outlined in Article 2:

"... (4) The present reasoned proposal sets out, in accordance with Article 7(1) TEU, the concerns of the Commission with regard to the rule of law in Poland. It invites the Council to determine, on the basis of the same provision, that there is a clear risk of a serious breach by the Republic of Poland of the rule of law which is one of the values referred to in Article 2 TEU.

(5) The concerns of the Commission relate to the following issues:

(1) the lack of an independent and legitimate constitutional review;

(2) the adoption by the Polish Parliament of new legislation relating to the Polish judiciary which raises grave concerns as regards judicial independence and increases significantly the systemic threat to the rule of law in Poland:

(a) the law on the Supreme Court; approved by the Senate on 15 December 2017.

(b) the law amending the law on the Ordinary Courts Organisation (law on Ordinary Courts Organisation'); published in the Polish Official Journal on 28 July 2017 and in force since 12 August 2017;

(c) the law amending the law on the National Council for the Judiciary and certain other laws ('law on the National Council for the Judiciary'); approved by the Senate on 15 December 2017;

(d) the law amending the law on the National School of Judiciary and Public Prosecution, the law on Ordinary Courts Organisation and certain other laws (law on the National School of Judiciary'); published in the Polish Official Journal on 13 June 2017 and in force since 20 June 2017. ..."

Source: Proposal for a Council Decision on the determination of a clear risk of a serious breach by the Republic of Poland of the rule of law COM/2017/0835 final. Available at: https://eur-lex.europa.eu/legal-content/EN/TXT/?uri=celex:52017PC0835

\section{Appendix 23}

President Barroso has referred to government officials' propensity to "Europeanize failure" on multiple occasions. In his 2013 State of the Union Address, he used the same language when discussing the EU's response to the Euro-crisis and the gap between how the EU is portrayed and what the EU actually does:

"...I cannot emphasise this enough: citizens will not be convinced with rhetoric and promises only, but only with a concrete set of common achievements. We have to show the many areas where Europe has solved problems for citizens. Europe is not the cause of problems, Europe is part of the solution."

"...Does anyone seriously believe that, if the euro had collapsed, we or our Member States would still have any credibility left internationally?”

"...I know some people out there will say Europe is to blame for the crisis and the hardship.

But we can remind people that Europe was not at the origin of this crisis. It resulted from mismanagement of public finances by national governments and irresponsible bebaviour in financial markets. 
We can explain how Europe has worked to fix the crisis. What we would have lost if we hadn't succeeded in upholding the single market, because it was under threat, and the common currency, because some people predicted the end of the euro. If we hadn't coordinated recovery efforts and employment initiatives."

'What I tell people is: when you are in the same boat, one cannot say: 'your end of the boat is sinking.' We were in the same boat when things went well, and we are in it together when things are difficult."

"...At the same time we must acknowledge that, in some areas, Europe still lacks the power to do what is asked of it. A fact that is all too easily forgotten by those, and there are many out there, who always like to nationalise success and Europeanise failure. Ultimately, what we have, and what we don't have, is the result of democratic decision-making. And I think we should remind people of that."

Source: September 11, 2013 State of the Union Address by European Commission President José Manuel Barroso. Available at https://ec.europa.eu/commission/presscorner/detail/en/SPEECH 13684

\section{Appendix 24}

In 2013, the European People's Party voted against the European Parliament's so-called "Tavares report," highlighting the alarming breakdown of constitutional democracy in Hungary. EPP President Manfred Weber defended the Hungarian Government and the EPP-member Fidesz party by emphasizing how the report was a partisan interference with an EPP government. Although allegations of bias and hypocrisy are also central to the jeopardy thesis, Weber's framing is predominantly partisan rather than legalistic:

"The EPP Group voted against the Tavares Report today. The Report is a wish list of the European leftist parties who aim to impose their own political agenda on Hungary. The European Parliament has no competence to act as a tribunal and tell people how they have to live..."

"The Tavares Report adopted today by the leftist parties goes far beyond the competence of the European Parliament. The EP does not have the right to interfere in issues such as defining marriage and references to Christianity in the Constitution. These belong solely to national competence. The dozens of legislative recommendations to the Hungarian Parliament and the setting-up of a monitoring procedure to assess their implementation have no legal basis and are totally unacceptable. The European Parliament must not turn itself into a Big Brother..."

"The EPP Group also denounces the use of double standards by the European Socialists. The Socialists are turning a blind eye to glaring breaches of European values in Socialist-led countries such as Bulgaria and Romania. This further proves the fact that their continuous attempts to condemn EPP-led governments is biased and politically motivated."

Source: July 3, 2013 EPP Press Release, "EP Report on Hungary: EPP Group Rejects the Use of Double Standards." Available at https://www.eppgroup.eu/newsroom/news/epp-group-rejects-theuse-of-double-standards

\section{Appendix 25}

In September 2013, Vice-President of the European Commission and EU Justice Commissioner Viviane Reding addressed the various crises facing the EU, but called particular attention to what she called the "rule of law crises": 
"The Union is a unique construction, as it is not bound together by force, by a common army or a common police force, but only by the strength of the rule of law - a "Community based on the rule of law" where all Member States need to be concerned if there are any deficiencies in the independence, efficiency or quality of the justice system in another Member State.

"In parallel to the economic and financial crisis, we also bave been confronted on several occasions with a true "rule of law" crisis. They included notably the Roma crisis in France in summer 2010; the Hungarian crisis that started at the end of 2011; and the Romanian rule of law crisis in the summer of 2012..."

Source: Viviane Reding, 'The EU and the Rule of Law - What next?', Speech/13/677, 4 September 2013. Available at: https://ec.europa.eu/commission/presscorner/detail/en/SPEECH 13684

\section{Appendix 26}

In September 2018, Jarosław Kaczyński delivered a defiant speech criticizing EU rule of law enforcement efforts in Poland. The speech was delivered before PiS supporters during a party convention in the leadup to local elections, and generated widespread newspaper coverage, including in Reuters:

Poland belongs in the European Union but should be careful not to be "infected by social diseases" that dominate the bloc, ruling Law and Justice (PiS) party leader Jaroslaw Kaczynski said on Sunday...

... He defended his party's democratic record and accused critics of serving "powerful interests and making deals with the mighty of the world", in an apparent jab at the close ties between the liberal opposition in Poland and Brussels.

"T had said we would face an uphill battle and that stones would be thrown," Kacaynski said.

"We are being attacked internally and from the outside ... in ways that discount the reality and aim to demean ... Poland," he said...

While underlining the need for Poland to remain inside the bloc, his party says the EU is forcing member states to conform to standards that contravene Poland's traditional family values...

Source: Pawel Sobczak and Pawel Florkiewicz, 'Defiant Kaczynski says Poland must avoid Eu's Social diseases'. Reuters, September 2, 2018. Available at: https://www.reuters.com/article/uspoland-politics-idUSKCN1LIOJ2

\section{Appendix 27}

In November 2018 - a few weeks after Jarosław Kaczyński attacked the EU's efforts to safeguard the rule of law as an attempt to infect Poland with 'social diseases' and 'demean' the country - European Council President Donald Tusk traveled to Lodz, Poland to hold the first rally on his home-country's soil since departing for Brussels to assume the Council Presidency. The rally marked a shift away from Tusk's previously careful and reluctant approach vis-à-vis the PiS government. The rally was covered by many news outlets, including Politico: 
The Polish people should rise up and "defeat today's Bolsheviks" in the country's ruling Law and Justice party, European Council President Donald Tusk told a crowd of over a thousand cheering supporters Saturday.

The former Polish prime minister's call — on the eve of the country's independence centenary - to form an opposition movement against the government, is his first mass rally in Poland since he left for Brussels in 2014. After years of treading carefully in domestic politics, it marks the beginning of an apparent run for president in elections slated for June 2020.

"Freedom has a future in Poland," Tusk told the crowd gathered at the "Freedom Games" conference, in a former power plant turned cultural center...

... Tusk's bombastic rhetoric contrasts with the more cautious approach to Polish politics he has hitherto adopted. Since becoming Council president, he has been careful not to intervene directly, only occasionally criticizing the ruling Law and Justice party (PiS) for breaching the rule of law in Poland...

Source: Broniatowski, Michal. 'Donald Tusk's call to defeat 'Bolsheviks' marks Polish political return.' Politico, November 10, 2018. Available at https://www.politico.eu/article/donald-tusks-callto-defeat-bolsheviks-marks-polish-political-return-aw-and-justice-party-pis-speech-in-lodz/

\section{Appendix 28}

In February 2019, Viktor Orban and the Fidesz party launched a media campaign alleging that the EU generally - and EPP-affiliated Commission President Juncker specifically - is part of a conspiracy led by philanthropist George Soros to flood Hungary with asylum seekers, undermine Hungarian sovereignty, and endanger its national security. The campaign included a poster diffused on social media depicting both Juncker and Soros, with bright red letters reading 'You have the right to know what Brussels is planning to do.' This media-driven rhetorical affront generated widespread newspaper coverage, including in the The Guardian, which chronicled the unusually swift condemnation that it provoked from the Commission:

The European commission has accused Viktor Orbán's government of a propagating a "shocking" and "ludicrous conspiracy theory", after Hungary launched a poster campaign targeting Jean-Claude Juncker.

Opening a new front against Brussels a few months before European elections, the poster shows the European commission president alongside the Hungarian-American philanthropist George Soros, a familiar target in Hungary.

"You bave the right to know what Brussels is planning to do," the poster says. On its official Facebook page, the Hungarian government says the poster is part of an information campaign to tell the public about Brussels' migration plans, which it claims "fundamentally endangered Hungary's safety".

Although the government has previously run a "Stop Brussels" campaign, the decision to use an image of Junker is an escalation in the Orban government's public relations war with the EU's most senior leaders...

In an unusually forceful rebuttal against a member state, Juncker's chief spokesman, Margaritis Schinas, said the commission had made a commitment "to fight disinformation and fake news" and this case was no exception. 
"The Hungarian government campaign beggars belief," he said. "Tt is shocking that such a ludicrous conspiracy theory has reached the mainstream to the extent it has. There is no conspiracy. Hungarians deserve facts not fiction."

...Hungary has always refused to take refugees under the quotas and continues to block an EU law that proposes a permanent redistribution system for asylum seekers. The poster refers to this theme, stating: "They want to introduce compulsory relocation quotas."

The government campaign also accuses Juncker and Soros of wanting "to weaken member states' rights to protect their own borders" and claims "they want ... migrants' visas"...

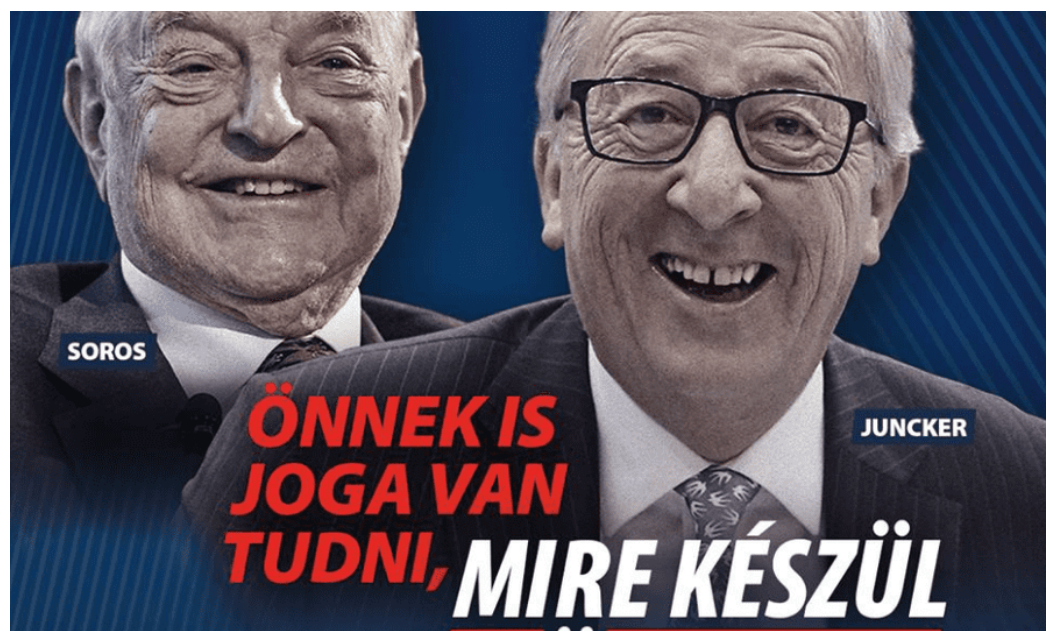

Source: Rankin, Jennifer. 'Brussels accuses Orbán of peddling conspiracy theory with Juncker poster.' The Guardian, February 19, 2019. Available at: https://www.theguardian.com/world/2019/feb/19/brussels-orban-jean-claude-juncker-postergeorge-soros-hungary

\section{Appendix 29}

In the months leading up to the selection of the new president of the European Commission, the leader of the EPP in the European Parliament - Manfred Weber, came under sustained criticism for his overt partisan coddling of Fidesz and Viktor Orban in Hungary. This provoked a last-minute pivot by Weber, who by the close of 2018 had embraced a sterner rhetoric condemning Orban. In the end, Weber's candidacy collapsed when the Socialists, Liberals, and Greens and some EPP parties objected to Weber for his partisan coddling, combined with Orban withdrawing his support for Weber as a result of his shift in rhetoric. These events were chronicled in an article in Politico:

Manfred Weber, whose bid to be European Commission president was firmly rejected by EU leaders, blamed French President Emmanuel Macron and Hungarian Prime Minister Viktor Orbán for his downfall, and said there were "powerful forces who did not want to accept the election result."

Weber was the center-right European People's Party's Spitzenkandidat, or lead candidate, in the European election. After the EPP emerged as the largest group in the election, despite losing seats, many in the EPP believed Weber should become Commission president... 
Orban withdrew bis support for Weber after the German pledged not to accept the position of Commission president if his success depended on the support of Hungary's ruling Fideszparty. Before then, Weber had faced a barrage of criticism from his opponents on the campaign trail regarding his close relationship with Orbán...

Source: Mischke, Judith. 'Very disappointed' Manfred Weber blames Macron and Orbán.' Politico, July 4, 2019. Available at: https://www.politico.eu/article/manfred-weber-disappointed-blamesemmanuel-macron-and-viktor-orban/

\section{Appendix 30}

The Hungarian government's claims that the Commission's proposed Rule of Law Mechanism was ultra vires appealed to other member states as well. First and foremost was the UK government which, in the years that would culminate in the Brexit referendum, was particularly keen to resist the slightest perception that new competences were being delegated to Brussels. In a December 2014 report, the government explicitly mobilized both the futility and jeopardy theses, agreeing that existing enforcement tools 'had so far proved ineffective' and had 'not proved a satisfactory mechanism,' yet simultaneously claiming that 'a further EU mechanism would risk undermining the clear roles for the Council and the European Council in this area':

Many contributors pointed to the distinction between the effectiveness of conditionality in ensuring (successfully) the full and proper transposition of EU law as set out on the acquis, and in ensuring (less successfully) full and proper adherence to the EU's values as set out in the Copenhagen Criteria. Most contributors believed that EU mechanisms to ensure compliance with its values, whether through previous attempts at post-accession monitoring or a new Treaty provision, had so far proved ineffective...

The German Council on Foreign Relations believed that 'a way to make the system fairer might be to apply a mechanism for the safeguard of democratic and rule-of-law standards on all Member States'. The German Foreign Minister had made a proposal for a new, light mechanism in 2012. However it noted that 'a mechanism of this kind would probably lead to an increase in EU competence in this area'...

Dmitry Kochenov proposed 'a greater role for the Council of Europe's Venice Commission, a leading body on terms of assessment of the rule of law', to help monitor and enforce values conditionality in the EU.

The UK Government believes it is vital for aspirant countries and new Member States to abide by the EU's values and democratic norms both pre-and post-accession. It also believes that the CVM [Cooperation and Verification Mechanism] has not proved a satisfactory mechanism, underlining the importance of addressing these issues prior to accession. However the Government does not accept the need for a new EU rule of law framework applying to all Member States. There are already mechanisms in place to protect EU common values and a further EU mechanism would risk undermining the clear roles for the Council and the European Council in this area... (pgs. 45-47)"

Source: UK Government, "Review of the Balance of Competences between the United Kingdom and the European Union - EU Enlargement," December 2014 report, available at: https://assets.publishing.service.gov.uk/government/uploads/system/uploads/attachment data/fil e/388422/BoC_EUEnlargement_acc.pdf

\section{Appendix 31}


Following a presentation by the Commission before the General Affairs Council in March of 2014 wherein it discussed its newly proposed Rule of Law Mechanism, several delegations in the Council requested a legal opinion from the Council Legal Service regarding the mechanism's validity. The Council Legal Service's subsequent non-public opinion of May 2014 is a clear example of the futility, jeopardy, and perversity theses all wrapped in one. First, the Legal Service claims that the EU's actions are limited in enforcing the rule of law to specific areas of EU competence, claiming that only the member states can take it upon themselves to rectify such deficiencies, and explicitly invoking the first utterance of the futility thesis by Commission President Barroso during his 2012 State of the Union address. Second, the Council argues that the Commission would jeopardize the Article 7 procedure and the functioning of the Council by creating new, parallel enforcement tools like the rule of law mechanism. Finally, the Council claims that the use of the Commission's Rule of Law Mechanism would, perversely, be illegal, because it would violate the principle of conferral:

"The support of the Council Legal Service was sought to clarify the institutional and procedural issues of relevance concerning the new mechanism suggested in the communication, before further consideration of the matter by the Council...

The Communication sets out a new EU Framework, for the rule of law to strengthen the capacity of the Union to ensure effective and equal protection of the rule of law in all Member States...

In his State of the Union address in 2012, the President of the European Commission expressed the view that the Union needed a better developed set of instruments as concerns the rule of law, not just the alternative between the "soft power" of political persuasion and the "nuclear option" of Article 7 TEU...

According to Article 5 TEU, "the limits of Union competences are governed by the principle of conferral". Its consequence is that "competences not conferred upon the Union in the Treaties remain within the Member States".

... Therefore, a violation of the values of the Union, including the rule of law, may be invoked against a Member State only when it acts in a subject matter for which the Union has competence based on specific competence-setting Treaty provisions.

Respect of the rule of law by the Member States cannot be, under the Treaties, the subject matter of an action by the institutions of the Union irrespective of the existence of a specific material competence to frame this action, with the sole exception of the procedure described at Article 7 TEU...

... Therefore, any request by the Council for a rule of law study and proposal by the Commission in the meaning of Article 241 TFEU could only be grounded in Article 7 TEU - which means that it could only lead to a reasoned proposal by the Commission, leaving the determination of a clear risk of a serious breach of the values to the Council, having obtained the consent of the European Parliament. It is not to be excluded that the Council may wish to make use of this possibility in specific circumstances. But to build a permanent mechanism for a rule of law study and proposal facility operated by the Commission on the combined bases of Article 7 TEU and Article 241 TFEU would undermine the specific character of the procedure of Article 7(1) particularly concerning the way it can be initiated.

Article 337 empowers the Commission to collect information and carry out checks required for the performance of the tasks entrusted to it (of which issuing reasoned opinions as foreseen by Article 7(1) TEU forms part) but this does not offer a legal basis for a new framework independent from Article 7. 
The same difficulty applies to Article 352 TFEU, which grants powers of action when no other basis is available to attain objectives of the Treaties, but which may only be invoked within the framework of the policies defined in the Treaties. It is apparent that respect of the values of the Union, including the rule of law, does not as such constitute a Union policy as foreseen by the Treaties.

It follows that there is no legal basis in the Treaties empowering the institutions to create a new supervision mechanism of the respect of the rule of law by the Member States, additional to what is laid down in Article 7 TEU, neither to amend, modify or supplement the procedure laid down in this Article. Were the Council to act along such lines, it would run the risk of being found to have abased its powers by deciding without a legal basis.

A solution compatible with the Treaties aimed at reinforcing the supervision of the respect of the rule of law, as such, by the Member States, however exists in the opinion of the Council Legal Service.

This solution is that Member States - and not the Council - agree on a review system of the functioning of the rule of law in the Member States, which may allow for the participation of the Commission6 and of other institutions if necessary, and on the consequences that Member States might engage to draw from such review...

Such a peer review approach, with a possible involvement of the institutions if so decided, could find its legal basis in an intergovernmental agreement designed to supplement the law of the Union and to ensure effective respect of the values on which the Member States have founded the Union, without by doing so conferring on the Union competences whose transfer the Treaties have not foreseen...

\section{CONCLUSION}

The Council Legal Service is of the opinion that the new EU Framework for the Rule of Law as set out in the Commission's communication is not compatible with the principle of conferral which governs the competences of the institutions of the Union. The possibility exists, however, for the Member States to agree among them on a review system of the functioning of the rule of law in the Member States and on the possible consequences to draw from that review. Such a review system as agreed by the Member States may foresee certain tasks to be carried out by the institutions of the Union." (pgs. 1-8)

Source: May 27, 2014 Opinion of the Council Legal Service Re-Commission's Communication on a New EU Framework to Strengthen the Rule of Law, available at: https://data.consilium.europa.eu/doc/document/ST-10296-2014-INIT/en/pdf

\section{Appendix 32}

In December 2014, the Council announced the creation of its own 'Rule of Law Dialogue' - a lessthan-subtle attempt to undermine any attempt by the Commission to side-step the Council and the Article 7 procedure and take action against the Hungarian government for attacking the rule of law. A press release of the December 16, 2014 General Affairs Council detailed the basis upon which this 'Rule of Law Dialogue' would unfold - that it would be based on a precise legal basis, would be applied equally to all member states by respecting mutual trust and sincere cooperation, respecting a nonpartisan and evidence-based approach. These would be the very norm-based arguments subsequently weaponized by the Hungarian and Polish governments to mobilize the perversity and jeopardy theses against the Council's Article 7 procedure (by claiming that it EU rule of law enforcement and actually 
undermine the rule of law, and that it would also jeopardize mutual trust and sincere cooperation by being mobilized hypocritically): "THE COUNCIL OF THE EUROPEAN UNION AND THE MEMBER STATES
MEETING WITHIN THE COUNCIL,

1. commit themselves to establishing a dialogue among all Member States within the Council to promote and safeguard the rule of law in the framework of the Treaties;

2. underline that this dialogue will be based on the principles of objectivity, non discrimination and equal treatment of all Member States;

3. agree that this dialogue will be conducted on a non partisan and evidence-based approach;

4. emphasize that such an approach will be without prejudice to the principle of conferred competences, as well as the respect of national identities of Member States inherent in their fundamental political and constitutional structures, inclusive of regional and local self-government, and their essential State functions, including ensuring the territorial integrity of the State, maintaining law and order and safeguarding national security, and should be brought forward in light of the principle of sincere cooperation.

5. agree that this dialogue will be developed in a way which is complementary with other EU Institutions and International Organisations, avoiding duplication and taking into account existing instruments and expertise in this area... (pg. 21)"

Source: December 16, 2014 Council Press Release - 3362 ${ }^{\text {nd }}$ Council Meeting, available at: https://www.consilium.europa.eu/media/24763/146348.pdf

\section{Appendix 33}

In January of 2012, Commission President Barroso and Hungarian Prime Minister Viktor Orbán addressed the European Parliament concerning the first rule of law-related infringements opened against Hungary. During his remarks, Orbán consistently invoked EU values and even construed the recent reforms of the Hungarian Constitution as an attempt to codify EU norms and principles into Hungarian law. He then appealed on the Parliament and the Commission to 'support' his reform efforts 'in the spirit of European values'. In response to some criticism of some MEPs, Orbán also began previewing the perversity and jeopardy theses, suggesting that support for an EU intervention in Hungary would be premised on incorrect facts and hypocrisy, which would undermine the very legal and democratic values it purported to defend:

"Mr President, thank you for giving me the opportunity to be here among you once more, half a year after the end of the Hungarian Presidency. It is always a pleasure to address a parliament, because no matter what an institutional system is like, it is in parliament where democracy is at work, and it is the parliament that is the heart of democracy. I myself share this opinion, and that is why I have been a member of parliament since $1990 \ldots$

...We undertook an enormous amount of work in the past one and a halfyears, and we are proud of that work. Although we still have to face plenty of serious economic difficulties, for the first time Hungary's budget can be considered stable and in compliance with European norms. We are in the process of reducing our sovereign debt, and our balance of payments is showing a long-term positive result. We bave outlawed and eliminated paramilitary organisations, and as a result Hungary now offers protection to all minorities, including national 
minorities, the Roma, as well as Jewish minorities, and the Hungarian Government will continue to protect these minorities in the future.

We were the last of the formerly occupied countries to enact a new constitution in place of the Communist one adopted in 1949. I would like to make it clear to you that the reform and reorganisation of Hungary took place on the basis of European values and principles. We drew upon both the good practices of the EU Member States and the fundamental documents of the European Union. Considering the extent and rate of the transformation I, together with everyone else in Hungary, consider it natural for disputes to emerge.

Today I sent a letter to President Barroso. In that letter I expressed my opinion that the issues raised by the Commission can be remedied in an easy, simple and swift manner. I anticipate quick results from our meeting scheduled for next week. At the same time I would like to inform Parliament that none of the passages which were sent to us by the Commission and with regard to which legal objections have been raised so far concern the Hungarian Constitution. Notwithstanding what newspapers publish, there has not been a single objection to the text of the Hungarian Constitution as adopted on 25 April. We adopted the constitution on 25 April last year. The Commission has raised objections regarding two of the temporary provisions related to the constitution, and I am at their disposal in order to remedy these two deficiencies, but I would like to point out that thus far no one has expressed any doubts of a legal nature in respect of any passage of the Hungarian Constitution. I am convinced that this is as it should be.

Ladies and gentlemen, I am grateful to you for allowing me to explain all this. I ask you to kindly continue to support in the future, in the spirit of European values, the major transformation and restructuring that we are in the process of completing in Hungary. Hungary is counting on the European Parliament's support. Thank. you for your attention...

\section{[following MEP statements]}

Ladies and gentlemen, due to the lateness of the hour allow me to forgo correcting every one of the unfortunately numerous factual mistakes that were made, and I therefore only ask those who made comments and criticised or accused Hungary and the Hungarian Constitution to please be so kind as to read that constitution. It is an exceptionally valuable document and one can find several novel things in it. The protection of minorities, the protection of sign languages, environmental protection, opposition to GMOs - these are all things that I believe are worthy of consideration by any European country...

Ladies and gentlemen, I also had the impression that this debate, which was about Hungary, had a European aspect as well, and was an ideological debate of sorts. People like me, and our political community, must accept that unfortunately the ideals we represent do not enjoy majority support in this House either. Our ideals are undoubtedly Christian and based on personal responsibility; we find national sentiment to be an important and positive thing, and we believe that families are the foundations of the future. It may be that a great many people believe otherwise, but that makes our position no less a European one. It may be that with this we are in a minority in Europe, but this position is no less a European position, and we are free to represent this conviction. You may disagree with what I will quote now, but I personally profess Schumann's view that there will either be a Christian democracy in Europe or there will be no democracy at all. This, ladies and gentlemen, is a European position.

As regards concrete details, allow me to avoid having the same debate here that we will have to conduct with the Commission on the specifics. I would only like to mention two concrete points here. We have no conflict with the Commission over the independence of the judiciary... 
... We Hungarians believe that what makes Europe Europe is its culture. In our view the foundations of European culture are goodwill and benevolence. There have always been and there always will be disputes in Europe, but as long as the arguments in these debates are specific, reasonable and sober, and as long as we assume the otherparty's good intentions we will always be able to find a way to resolve these disputes. It grieves me that in today's debate I was on many occasions presented not with arguments and concrete facts, but with absurd factual errors, vehemence, rage and prejudice. I am convinced that accusations made without knowledge of the laws under discussion are unbecoming Europe, as are judgements motivated not by common sense and objectivity but partisan rage and vehemence. We Hungarians, and I myself, believe in these principles, and it is these principles that guided us to the European Union, and we ask everyone to return to the European way of resolving disputes...

Source: January 18, 2012 European Parliament Debate Re-Recent Political Developments in Hungary, available at: https://www.europarl.europa.eu/doceo/document/CRE-7-2012-01-18-ITM021 EN.html?redirect

\section{Appendix 34}

On July $2^{\text {nd }}$, 2013, Hungarian Prime Minister Viktor Orbán made a surprise visit to the European Parliament to lambast the Tavares report that had just been presented for approval by the Parliament. During the debate, Orbán addressed both Commission President Barroso (who was Present) and the Parliament by weaponizing the perversity and the jeopardy thesis: He claimed that the report's endorsement of EU enforcement actions in Hungary to defend the rule of law symbolized a 'serious danger, a threat to Europe', and was being deployed using hypocritical 'double standards' that would undermine mutual trust amongst member states and be potentially wielded to interfere in any EU state in the future:

"The report is very unfair vis-a-vis Hungary, very unfair vis-a-vis the people of Hungary. You are applying double standards in this report, there's no recognition of certain enormous efforts that have been deployed in Hungary in order to help modernize the country. This is simply forgotten, denied...

The report that is tabled before you today is a serious danger, a threat for Europe (...) You're suggesting here setting up a mechanism, an institution which is not anchored in the treaties and it would mean that member states of the union could find themselves under guardianship in the future..."

Source: “Viktor Orban angry at EU's criticism of Hungary's democratic values." Euractiv, July 3, 2013. Available at: https://www.euractiv.com/section/central-europe/video/viktor-orban-angry-at-eu-scriticism-of-hungary-s-democratic-values/

\section{Appendix 35}

As early as December 2010, we have evidence that the Hungarian government tried to stall the Commission's opening of infringement proceedings by setting the groundwork for the jeopardy thesis: Rule of law-related enforcement in Hungary - in this instance, over its reform of the Hungarian media system - would be targeting and discriminating against Hungary for common practices across Member States. In subsequent discursive interactions, the Hungarian government would explicitly tie such alleged discriminatory acts to undermining hard-won and fundamental EU legal principles, like mutual 
trust amongst member states. The following evidence is from a leak to the Financial Times of an exchange of letters in December 2010 between European Media Commissioner Neelie Kroes and Hungarian Deputy Prime Minister Tibor Navracsics:

We got our hands on Kroes' four-page letter to Hungary's deputy prime minister... Although Kroes' letter has not gotten a buge amount of attention, it undercuts one of Orban's Fidesz party's most effective arguments at home - that last year's broubaha over the controversial media law was overblown and that Budapest and Brussels have patched up their differences over the measure.

Kroes makes clear that's not the case:

"In your letter of 29 December 2010, you stated that no part of the Hungarian media regulation contains provisions not found in the legislation of one or more Member States. However, a recent analysis indicates that Hungary's media laws may go beyond the European practices and norms cited by you."

Orban may still wiggle his way out. Several diplomats believe the parliament's efforts to strip Hungary of its voting rights will come to naught, and Orban has proven himself wily enough to make just enough concessions to Brussels that such controversies blow over...

Source: Spiegel, Peter. “The Daily Hungarian: Orban faces more heat.” Financial Times, January 20, 2012, available at: https://www.ft.com/content/5a8db263-2852-37d5-a769-75aeae2e23ee

\section{Appendix 36}

Hungarian Prime Minister Viktor Orbán's norm-based discursive interactions with EU institutions and his capacity to back them up and render them plausible by wielding his party's near-hegemonic influence over legislative policymaking in Hungary - is what Orbán liked to label the "dance of the peacock." This strategy - and its direct attribution to the Hungarian Prime Minister - has been described by several scholars and journalists, including in a January 2019 article The New Yorker:

For the past seven years, Orban has used a maneuver that he has called the "dance of the peacock." His government would insert measures into new laws precisely for the purpose of removing them. "He'll generally put in one outrageous thing and one super-outrageous thing," Kim Lane Scheppele, a legal scholar at Princeton who studies Hungary, told me. "But the super-outrageous thing isn't really necessary-it's designed to be jettisoned." When the European Parliament or the European Commission has challenged Orbán's government on the antidemocratic measures, he has made a few symbolic gestures of conciliation, "as if," he has said, "we would like to make friends with them."

Source: Zerofsky, Elisabeth. Viktor Orbán's Far-Right Vision for Europe. The New Yorker, January 7, 2019, available at: https://www.newyorker.com/magazine/2019/01/14/viktor-orbans-far-rightvision-for-europe 